\title{
The impacts of European and Asian anthropogenic sulphur dioxide emissions on Sahel rainfall
}

Article

Published Version

Open Access

Dong, B., Sutton, R. T., Highwood, E. and Wilcox, L. (2014) The impacts of European and Asian anthropogenic sulphur dioxide emissions on Sahel rainfall. Journal of Climate, 27 (18). pp. 7000-7017. ISSN 1520-0442 doi:

https://doi.org/10.1175/JCLI-D-13-00769.1 Available at https://centaur.reading.ac.uk/37053/

It is advisable to refer to the publisher's version if you intend to cite from the work. See Guidance on citing.

To link to this article DOI: http://dx.doi.org/10.1175/JCLI-D-13-00769.1

Publisher: American Meteorological Society

All outputs in CentAUR are protected by Intellectual Property Rights law, including copyright law. Copyright and IPR is retained by the creators or other copyright holders. Terms and conditions for use of this material are defined in the End User Agreement.

www.reading.ac.uk/centaur 
Central Archive at the University of Reading

Reading's research outputs online 


\title{
${ }^{\curvearrowright}$ The Impacts of European and Asian Anthropogenic Sulfur Dioxide Emissions on Sahel Rainfall
}

\author{
Buwen Dong AND Rowan T. SUTTON \\ National Centre for Atmospheric Science, Department of Meteorology, University of Reading, Reading, United Kingdom \\ ELLIE HIGHWOOD \\ Department of Meteorology, University of Reading, Reading, United Kingdom \\ LAURA WILCOX \\ National Centre for Atmospheric Science, Department of Meteorology, University of Reading, Reading, United Kingdom
}

(Manuscript received 11 December 2013, in final form 11 June 2014)

\begin{abstract}
In this study, the atmospheric component of a state-of-the-art climate model [the Hadley Centre Global Environment Model, version 2-Earth System (HadGEM2-ES)] has been used to investigate the impacts of regional anthropogenic sulfur dioxide emissions on boreal summer Sahel rainfall. The study focuses on the transient response of the West African monsoon (WAM) to a sudden change in regional anthropogenic sulfur dioxide emissions, including land surface feedbacks but without sea surface temperature (SST) feedbacks. The response occurs in two distinct phases: 1) fast adjustment of the atmosphere on a time scale of days to weeks (up to 3 weeks) through aerosol-radiation and aerosol-cloud interactions with weak hydrological cycle changes and surface feedbacks and 2) adjustment of the atmosphere and land surface with significant local hydrological cycle changes and changes in atmospheric circulation (beyond 3 weeks).

European emissions lead to an increase in shortwave (SW) scattering by increased sulfate burden, leading to a decrease in surface downward SW radiation that causes surface cooling over North Africa, a weakening of the Saharan heat low and WAM, and a decrease in Sahel precipitation. In contrast, Asian emissions lead to very little change in sulfate burden over North Africa, but they induce an adjustment of the Walker circulation, which leads again to a weakening of the WAM and a decrease in Sahel precipitation. The responses to European and Asian emissions during the second phase exhibit similar large-scale patterns of anomalous atmospheric circulation and hydrological variables, suggesting a preferred response. The results support the idea that sulfate aerosol emissions contributed to the observed decline in Sahel precipitation in the second half of the twentieth century.
\end{abstract}

\section{Introduction}

Sahelian rainfall is controlled by the West African monsoon (WAM). The region experienced severe drought in the 1970s-1980s (e.g., Folland et al. 1986; Zeng et al. 1999; Giannini et al. 2003; 2013; Held et al.

๖ Denotes Open Access content.

Corresponding author address: Buwen Dong, Department of Meteorology, University of Reading, Earley Gate, Reading RG6 6BB, United Kingdom.

E-mail: b.dong@reading.ac.uk
2005; Kawase et al. 2010; Mohino et al. 2011; Martin and Thorncroft 2014; Dai 2013; Haywood et al. 2013; Martin et al. 2014) that has been attributed to a number of possible causes. These include decadal changes in sea surface temperatures (SSTs) in the Indian Ocean (e.g., Bader and Latif 2003; Biasutti et al. 2008;Lu 2009) and Atlantic Ocean resulting either from natural variability such as changes in the Atlantic meridional overturning circulation (Kerr 2000; Knight et al. 2006; Zhang and Delworth 2006) or from externally forced variability (both anthropogenic and natural) (Ackerley et al. 2011; Booth et al. 2012; Haywood et al. 2013) and changes in vegetation and African dust (Charney 1975; Zeng et al. 1999; Yoshioka et al. 2007; Huang et al. 
2009; Lau et al. 2009; Wang et al. 2012; Kucharski et al. 2013).

Many of the most recent studies have emphasized the possible role of aerosols in producing both the drought and the more recent recovery (Nicholson 2013). Rotstayn and Lohmann (2002), Held et al. (2005), Ackerley et al. (2011), Chang et al. (2011), Booth et al. (2012), and Hwang et al. (2013) all suggested that an increase in the concentration of sulfate aerosols over the Northern Hemisphere in the 1970s-1980s cooled SSTs in the North Atlantic, creating an interhemispheric SST gradient, subsequently leading to a southward shift of the ITCZ in the Atlantic, weakening the WAM and resulting in the drying of the Sahel. Recently, Haywood et al. (2013) suggested that explosive volcanic eruptions can shift the normal summer monsoon rainfall in North Africa. This causes either a wet or dry Sahel, depending on whether the volcanic aerosols are loaded preferentially into the Southern or Northern Hemisphere, respectively, since this affects the crossequatorial SST gradient and subsequently the northward extension of African summer monsoon rainfall.

Many of these studies emphasized the link between aerosol changes and SST feedbacks. However, aerosols would also be expected to alter the surface and atmospheric radiation balance on time scales much shorter than SST response time scales. Aerosols can affect cloud and precipitation through aerosol-radiation interactions and aerosol-cloud interactions (e.g., Rosenfeld et al. 2008; Tao et al. 2012). By scattering and absorption of solar radiation, aerosols can change surface and atmospheric temperature and further modulate cloud formation (e.g., Hansen et al. 1997). Aerosol interacts directly with cloud by serving as cloud condensation nuclei $(\mathrm{CCN})$ or ice nuclei (IN), leading to changes in cloud droplet number concentration (CDNC), cloud droplet size, cloud radiative properties, and precipitation efficiency (e.g., Twomey 1977; Rosenfeld et al. 2008). The radiative and cloud processes can interact with each other and produce complex aerosol effects on clouds and precipitation, both locally and remotely (e.g., Chou et al. 2005; Tao et al. 2012; Bollasina et al. 2014). Therefore, anthropogenic aerosols might affect the WAM development and Sahel precipitation even without causing SST changes, since they interact with both shortwave (SW) and longwave (LW) radiation, and modify the radiative and physical properties of clouds in the absence of SST feedbacks.

In this study, we investigate the transient responses to an abrupt change in sulfur dioxide emissions from specific regions (Asia and Europe) in order to study physical processes of the WAM changes using simulations with an atmospheric general circulation model excluding SST feedbacks. A similar approach was used in Dong et al. (2009) to investigate the transient adjustment of atmosphere and land surface in response to an instantaneous doubling of $\mathrm{CO}_{2}$. By investigating the transient evolution with daily time resolution we are able to disentangle processes evolving on different time scales. In addition, we are able to investigate to what extent the processes that govern responses to sulfur dioxide emissions from different regions (Asia and Europe) are similar or different.

The structure of the paper is as follows. Section 2 describes the model used and experiments performed. Section 3 presents seasonal mean responses of the WAM and Sahel rainfall. Section 4 discusses the time evolution of responses and elucidates the physical processes involved. Conclusions are in section 5.

\section{Model and experiments}

\section{a. Model and experiments}

The model used is the atmospheric component of the Met Office Hadley Centre Global Environment Model, version 2-Earth System (HadGEM2-ES) (Collins et al. 2011; Jones et al. 2011; Bellouin et al. 2011). The atmospheric resolution is $\mathrm{N} 96\left(1.875^{\circ} \times 1.25^{\circ}\right)$ with 38 vertical levels and the model top at $\sim 39 \mathrm{~km}$. HadGEM2-ES includes an interactive land and ocean carbon cycle as well as a dynamic vegetation model. The model includes Earth System components such as an interactive tropospheric chemistry scheme and eight species of tropospheric aerosols considering the aerosol direct, indirect, and semidirect effects. Detailed descriptions of the aerosol module of HadGEM2 can be found inBellouin et al. (2011). The historical emissions for tropospheric aerosols and aerosol precursors are described by Lamarque et al. (2010). Datasets required by HadGEM2-ES for tropospheric aerosol modeling are emissions of sulfur dioxide $\left(\mathrm{SO}_{2}\right)$, land-based dimethyl sulfide (DMS), ammonia $\left(\mathrm{NH}_{3}\right)$, and primary black and organic carbon aerosols from fossil fuel combustion and biomass burning. Emissions of sea salt, mineral dust, and ocean-based DMS are computed interactively so emission datasets are not required. HadGEM2-ES participates in the Coupled Model Intercomparison Project phase 5 (CMIP5) simulations and the validation of model aerosols and their radiative forcing has been documented in Bellouin et al. (2011).

Figure 1 shows the annual mean emissions of $\mathrm{SO}_{2}$ in 2000 (Lamarque et al. 2010). South and East Asia is one of the three largest emission regions in the world, alongside western Europe and the east coast of the United States. To investigate the impacts of regional sulfur dioxide emissions on Sahel precipitation, a set of experiments is performed (summarized in Table 1). The CONTROL experiment is forced by monthly climatological SST and sea ice averaged over the period 1986-2005 from the Hadley Centre Global 


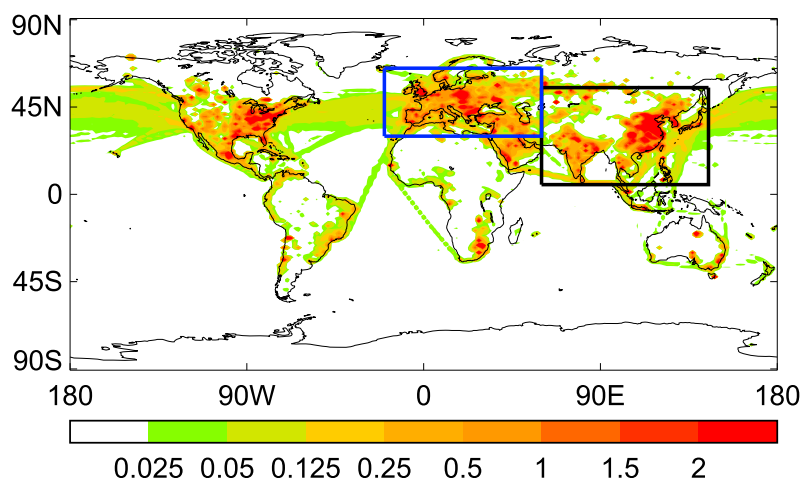

FIG. 1. Annual mean sulfur dioxide emissions $\left(\mathrm{g} \mathrm{m}^{-2} \mathrm{yr}^{-1}\right)$ in year 2000 with the black and blue boxes highlighting Asia and Europe where emissions are set to zero in sensitivity experiments (Table 1).

Sea Ice and Sea Surface Temperature dataset (HadISST) (Rayner et al. 2003), with well-mixed greenhouse gas concentrations and all species of aerosol and related emissions as in 2000. The sulfur dioxide emissions have seasonal cycles, but they are very weak (not shown). Two sensitivity experiments, NO-EUROPE and NO-ASIA, have been performed in which the emissions over Europe or Asia have been removed, respectively, with everything else remaining as in the control.

To separate externally forced variability from internal variability and to study transient adjustment processes, an ensemble of 30 integrations, each 3 months long starting from 1 June with daily outputs, differing only in their initial conditions, is performed for each experiment (e.g., Dong et al. 2009). The same 30 sets of initial conditions are used for each experiment, and they are from 1 to 30 June of the fifth year of a spinup integration, which is forced with climatological SST and sea ice, and with well-mixed greenhouse gases concentrations and all species of aerosol emissions at 2000 values. The response to the European sulfur dioxide emissions is estimated as the difference between the ensemble means of the CONTROL and NO-EUROPE experiments and the response to Asian emissions as the difference between the CONTROL and NO-ASIA experiments with an assumption that these forcings add up linearly. The ensemble mean across 30 members to a large extent removes the model's internal variability and allows for an assessment of the daily adjustment of the atmospheric circulation and land surface processes.

\section{b. Model climate over North Africa}

In this section some climatological features of the CONTROL experiment are compared with observed features. Figures $2 a$ and $2 b$ show the observed rainfall from the Global Precipitation Climatology Project (GPCP) (Adler et al. 2003), sea level pressure (SLP) from the Hadley Center mean sea level pressure dataset, version 2 (HadSLP2) (Allan and Ansell 2006), and 850-hPa wind from the National Centers for Environmental Prediction (NCEP) reanalysis (Kalnay et al. 1996). The climatology of precipitation over the Sahel from the Climatic Research Unit (CRU) time series, version 3.1.1 (TS3.1.1), dataset (Harris et al. 2013) is very similar to Fig. 2a (not shown). Figures $2 \mathrm{c}$ and $2 \mathrm{~d}$ show the corresponding model climatologies in the CONTROL experiment. Overall, the rainfall distribution is reasonably well reproduced. For example, the regions where precipitation is greater than $8.0 \mathrm{~mm} \mathrm{day}^{-1}$ at about $0^{\circ}, 10^{\circ} \mathrm{E}$ and at about $5^{\circ} \mathrm{N}$ on the west coast of the Sahel are well captured by the model. However, the model-simulated precipitation does not extend northward enough in comparison with observations, with the $1.0 \mathrm{~mm} \mathrm{day}^{-1}$ extent being at about $15^{\circ} \mathrm{N}$ in the model while it is at about $18^{\circ} \mathrm{N}$ in observations.

The main features of the large-scale circulation are reproduced reasonably well in comparison with observations and reanalysis (Figs. 2b,d). The large-scale North Atlantic anticyclone and trade winds over the tropical Atlantic are well captured by the model. The position of the Saharan heat low and its strength also compare well with observations. Associated with the Saharan heat low are strong southwesterly monsoon winds around $\sim 10^{\circ} \mathrm{N}$, to the south of the heat low, and northeasterly winds to the north in observations. The model simulates well the northeasterlies to the north of the heat low, but underestimates the southwesterly monsoon winds to the south.

\section{c. Observed multidecadal change in Sahel rainfall}

Sahel precipitation is well known to have undergone large multidecadal variability over the past century with

TABLE 1. Summary of numerical experiments.

\begin{tabular}{llc}
\hline \hline Experiments & \multicolumn{1}{c}{ Boundary conditions } & $\begin{array}{c}\text { Transient experiments } \\
\text { (for JJA) }\end{array}$ \\
\hline CONTROL & Monthly climatological SST and sea ice averaged over the period of 1986 to 2005 using & 30 members \\
& HadISST (Rayner et al. 2003). Sulfur dioxide, soot, biogenic aerosols, biomass-burning, & \\
& and fossil fuels and organic carbon at 2000 emissions. Greenhouse gases concentrations & \\
NO-EUROPE & at 2000. No natural forcing variation (e.g., solar, volcanic). & 30 members \\
NO-ASIA & As in CONTROL, but without anthropogenic sulfur dioxide emissions over Europe & 30 members \\
\hline
\end{tabular}


(a) Precipitation in JJA (GPCP)
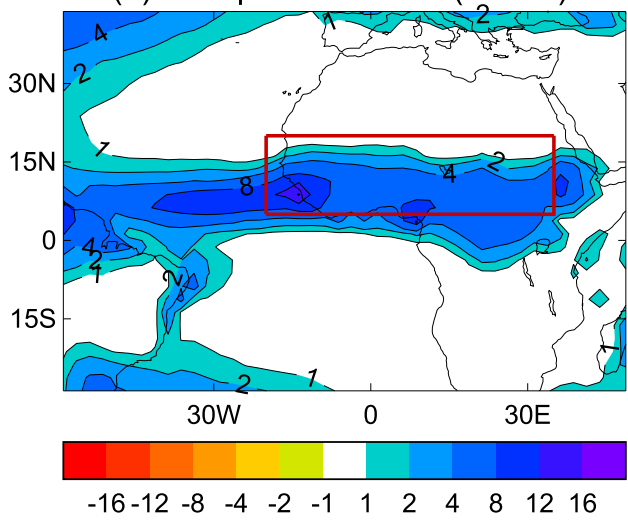

(c) Precipitation in JJA (HadGEM2-ES)

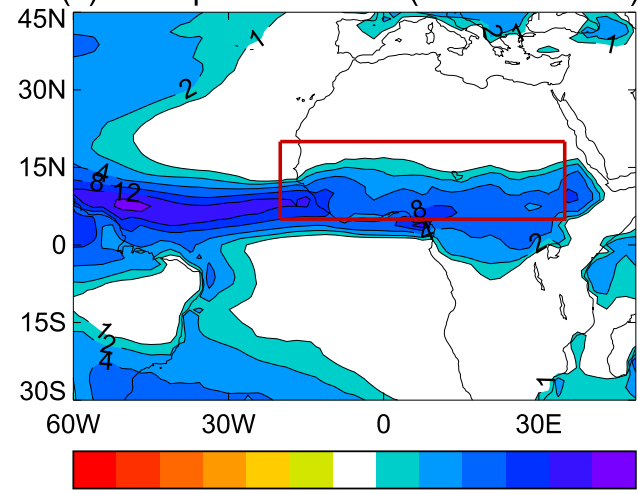

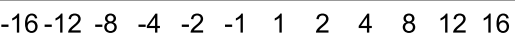

(e) Precipitation (1964to1993-1931to1960)

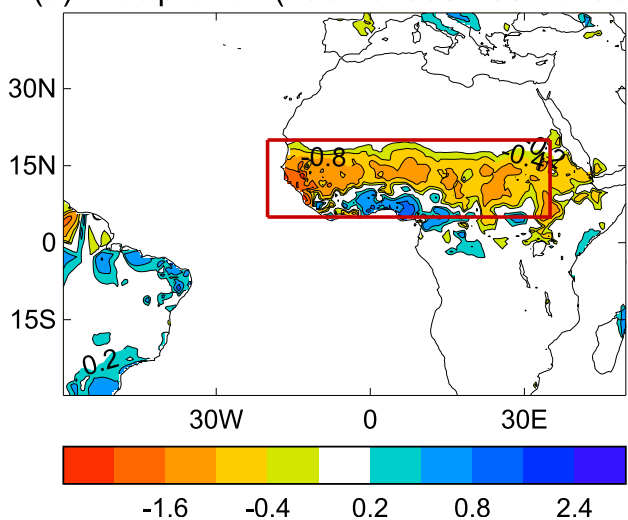

wet conditions in the 1940s and 1950s and severe drought in the 1970s and 1980s (e.g., Folland et al. 1986; Martin and Thorncroft 2014). To illustrate the switch to dry conditions around the 1960s the difference in precipitation between two periods 1964-93 and 1931-60 from the CRU TS3.1.1 is shown in Fig. 2e. Associated with the switch to the dry conditions around the 1960s is a decrease in precipitation about $0.8-1.6 \mathrm{~mm} \mathrm{day}^{-1}$ centered in the Sahel region. Farther to the south, there is an overall increase in precipitation of about 0.4 $0.8 \mathrm{~mm} \mathrm{day}^{-1}$ in the equatorial region. The area-averaged (b) $850 \mathrm{hPa}$ wind and SLP in JJA (Obs)

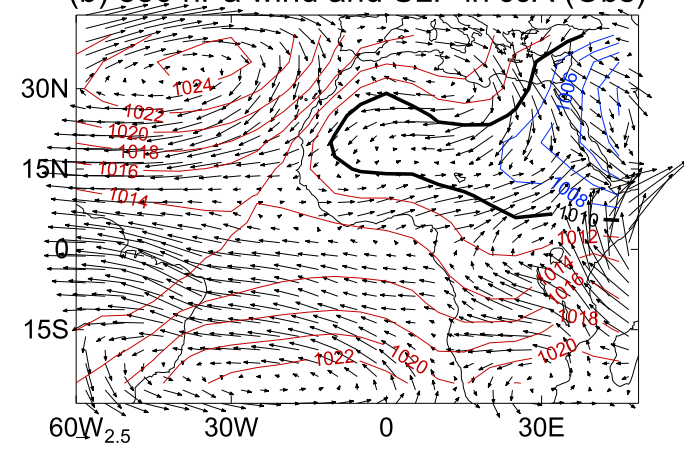

(d) $850 \mathrm{hPa}$ wind and SLP in JJA (HadGEM-ES)

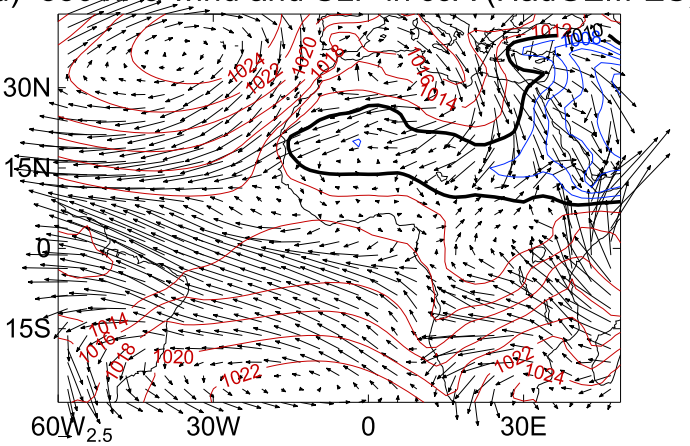

FIG. 2. The spatial patterns of June-August (JJA) climatology for precipitation $\left(\mathrm{mm} \mathrm{day}^{-1}\right)$, SLP (hPa), and 850-hPa winds $\left(\mathrm{m} \mathrm{s}^{-1}\right)$ in (a),(b) observations and (c),(d) the model CONTROL experiment. (e) Precipitation difference $\left(\mathrm{mm} \mathrm{day}^{-1}\right)$ between two periods (1964-93 minus 1931-60) based on the CRU TS3.1.1 dataset. The scale of wind arrow is on the left bottom in (b) and (d). Red box in (a), (c), and (e) is the Sahel.

precipitation change over the Sahel $\left(5^{\circ}-20^{\circ} \mathrm{N}, 20^{\circ} \mathrm{W}-35^{\circ} \mathrm{E}\right)$ is $-0.48 \mathrm{~mm} \mathrm{day}^{-1}$.

\section{Seasonal mean responses to regional sulfur dioxide emissions}

\section{a. Seasonal mean changes of aerosol burden}

The June-August (JJA) mean changes in aerosol burdens in response to regional sulfur dioxide emissions are illustrated in Fig. 3. European emissions induce large 
(a) Sulphate burden in JJA (Europe)

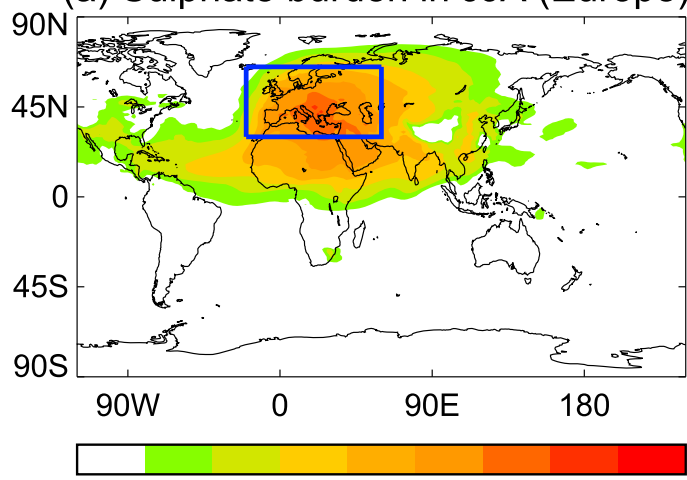

$\begin{array}{llllllll}0.1 & 0.2 & 0.5 & 1 & 2 & 4 & 8 & 16\end{array}$

(c) CDNC in JJA (Europe)

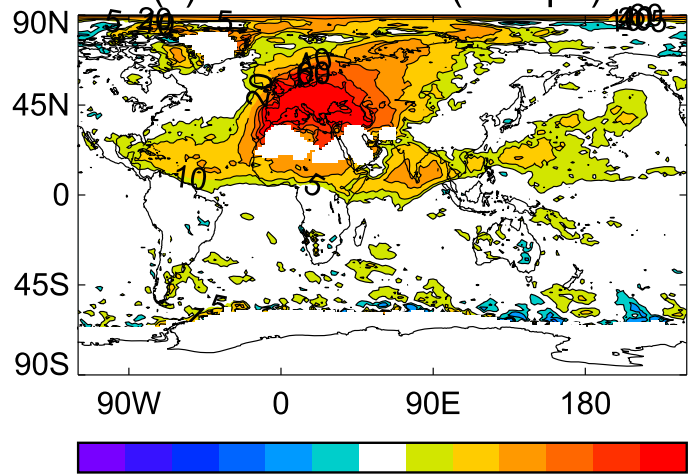

$-80-60-40-20-10-5 \quad 5 \quad 1020406080$

(e) CDER in JJA (Europe)

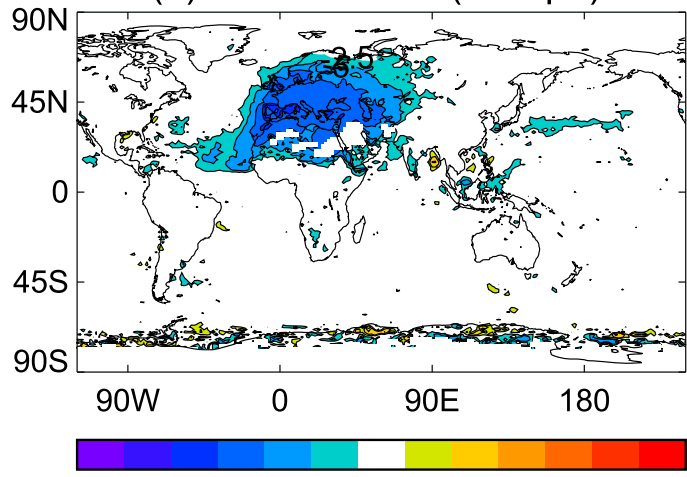

$-40-30-20-10-5-2.52 .5510203040$ (b) Sulphate burden in JJA (Asia)

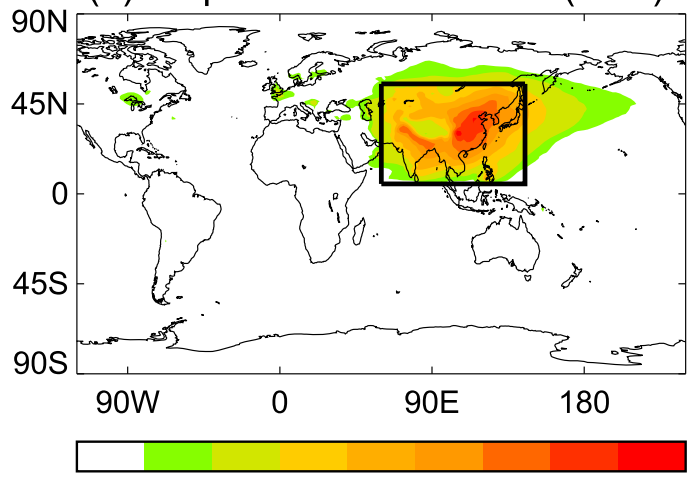

$\begin{array}{llllllll}0.1 & 0.2 & 0.5 & 1 & 2 & 4 & 8 & 16\end{array}$

(d) CDNC in JJA (Asia)

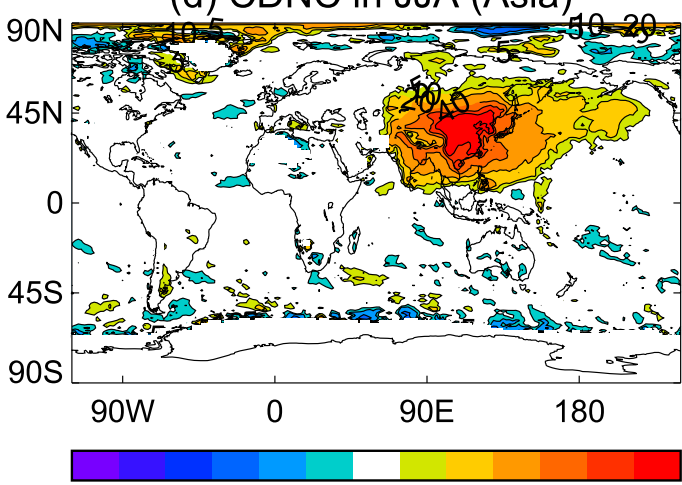

$-80-60-40-20-10-5 \quad 5 \quad 1020406080$

(f) CDER in JJA (Asia)

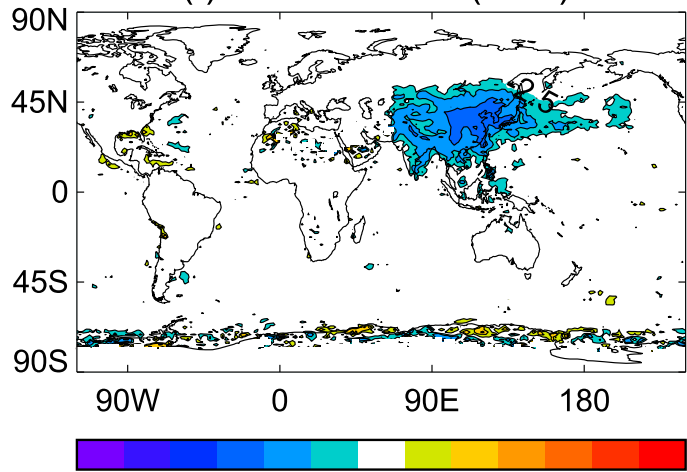

$-40-30-20-10-5-2.52 .5510203040$

FIG. 3. The spatial patterns of (a),(b) changes in sulfate aerosol burden $\left(\mathrm{mg} \mathrm{m}^{-2}\right)$, (c),(d) percentage changes in cloud droplet number concentration (CDNC), and (e),(f) percentage changes in cloud droplet effective radius (CDER) in response to European and Asian sulfur dioxide emissions in JJA. The blue and black boxes in (a) and (b) highlight Europe and Asia where emissions are perturbed.

increases in sulfate burden not only over Europe, but also downstream over Asia, Africa, and the tropical and subtropical Atlantic (Fig. 3a). Over Europe and the Mediterranean the increases in sulfate burden are associated with increases in cloud droplet number concentration (by more than $80 \%$ ) and decreases in cloud droplet effective radius (CDER) (by 10\%-20\%). There are also $10 \%-20 \%$ increases in CDNC over the tropical Atlantic and African monsoon region, the Arabian Sea, and South and Southeast Asia (Fig. 3c) and decreases in CDER by $2.5 \%-10 \%$ over the same regions (Fig. $3 \mathrm{e}$ ). Asian emissions lead to more localized increases in 
(a) SAT (Europe)

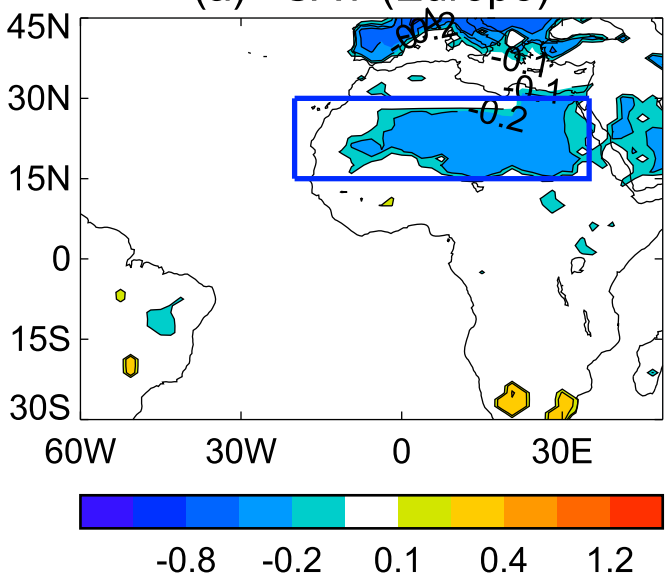

(c) precipitation (Europe)

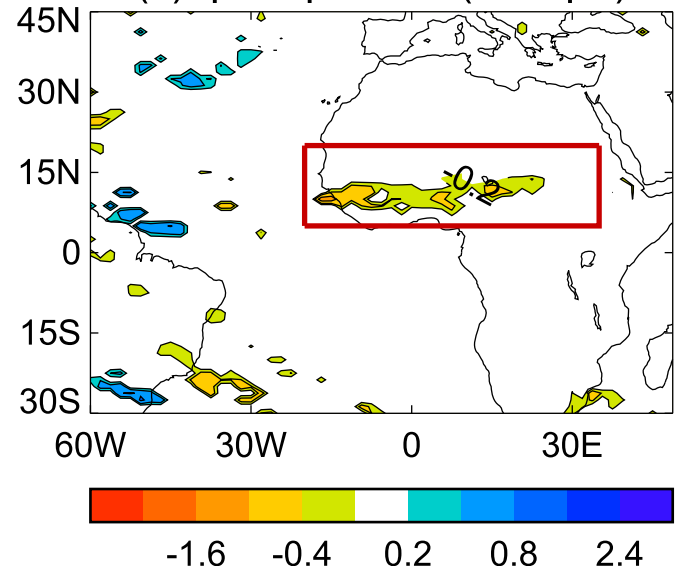

(b) SAT (Asia)

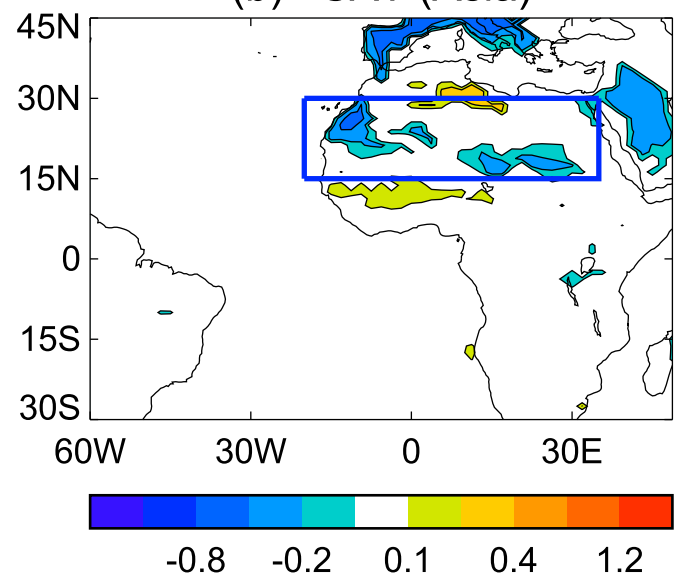

(d) precipitation (Asia)

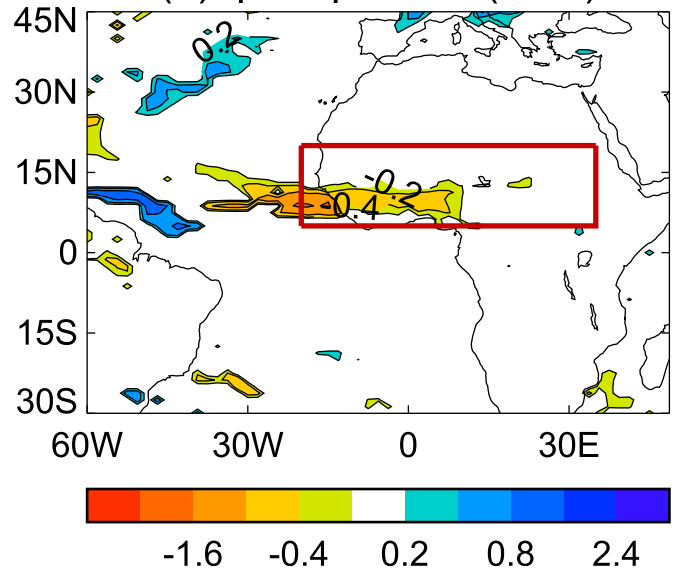

FIG. 4. The spatial patterns of changes in (a),(b) surface air temperature $\left({ }^{\circ} \mathrm{C}\right)$ and $(\mathrm{c}),(\mathrm{d})$ precipitation $\left(\mathrm{mm} \mathrm{day}^{-1}\right)$ in response to European and Asian sulfur dioxide emissions in JJA. Only changes that are statistically significant at the $90 \%$ confidence level using a two-tailed Student's $t$ test are shown. The blue and red boxes highlight North Africa and the Sahel.

sulfate burden over the emission area and relatively small increases downstream over the western North Pacific (Fig. 3b) with associated increases in CDNC (Fig. 3d) and decreases in CDER (Fig. 3f).

\section{b. Seasonal mean responses in surface air temperature and precipitation over North Africa}

The seasonal mean changes in surface air temperature (SAT) and precipitation in response to European and Asian sulfur dioxide emissions are illustrated in Fig. 4. European emissions lead to a decrease in SAT $\left(\sim 0.2^{\circ}-0.4^{\circ} \mathrm{C}\right)$ over North Africa and over the Arabian Peninsula. Accompanying this cooling is a decrease $\left(\sim 0.2-0.3 \mathrm{~mm} \mathrm{day}^{-1}\right)$ in precipitation over the Sahel. Interestingly, Asian emissions also lead to a surface cooling over North Africa and reduced precipitation $\left(\sim 0.2-0.4 \mathrm{~mm} \mathrm{day}^{-1}\right)$ over the western Sahel despite the changes in sulfate burden, CDNC, and
CDER in response to Asian emissions being very small over North Africa (Fig. 3). This suggests a remote response of the WAM to Asian emissions. The patterns of precipitation changes in response to both European and Asian emissions show similar features with decreased precipitation over the Sahel and increased precipitation over the western tropical Atlantic, suggesting a preferred mode of response. However, the decrease in precipitation over the Sahel does not extend northward enough in comparison with observed changes (Fig. 2e) and this is presumably related to the model deficiency that the simulated climatological precipitation does not extend northward enough. The direct responses to European and Asian sulfur dioxide emissions without SST feedback give a change in Sahel precipitation of -0.12 and $-0.13 \mathrm{~mm} \mathrm{day}^{-1}$ respectively (Table 2). 
TABLE 2. Area-averaged responses in JJA for precipitation and column integrated water vapor transport convergence over the Sahel $\left(5^{\circ}-20^{\circ} \mathrm{N}, 20^{\circ} \mathrm{W}-35^{\circ} \mathrm{E}\right)$. Area-averaged precipitation difference in observations between the two periods (1964-93 minus 1931-60) is $-0.48 \mathrm{~mm}$ day $^{-1}$.

\begin{tabular}{lcc}
\hline \hline & European impact & Asian impact \\
\hline Precipitation $\left(\mathrm{mm} \mathrm{day}^{-1}\right)$ & -0.123 & -0.134 \\
Convergence of vertically integrated water vapor transport $\left(\mathrm{kg} \mathrm{m}^{-2} \mathrm{day}^{-1}\right)$ & -0.116 & -0.142 \\
Convergence of vertically integrated water vapor transport due to change in & -0.117 & -0.117 \\
$\quad$ circulation $\left(\mathrm{kg} \mathrm{m}^{-2} \mathrm{day}^{-1}\right)$ & & \\
\hline
\end{tabular}

We now consider in more detail the mechanisms leading to weakened WAM and reduced precipitation by examining the time evolution of the response.

\section{Time evolutions of WAM response}

Transient time evolutions (5-day mean) of atmospheric and land surface responses over North Africa to a sudden change in regional sulfur dioxide emissions are illustrated in Fig. 5 while the time evolutions of responses in temperature and specific humidity with height are illustrated in Fig. 6. These transient evolutions reveal two distinct time scales of responses: 1 ) a very fast adjustment of the atmosphere, without hydrological cycle changes (up to 3 weeks), and 2) responses of the atmosphere and surface with significant local hydrological cycle changes and associated feedbacks (beyond 3 weeks). Figure 6 shows that the second phase is associated with drying of the troposphere (reduced specific humidity) over North Africa in response to both European and Asian emissions. Cooling also occurs in both experiments, but there are differences in vertical structure: in response to European emissions there is cooling at the surface as well as in the upper troposphere, whereas in response to Asian emissions, only upper tropospheric cooling - corresponding to an increase in lapse rate-is apparent.

\section{a. Fast adjustment (up to 20 days)}

The spatial patterns of time mean changes in sulfate aerosol optical depth (AOD) during the first 20 days are illustrated in Fig. 7. The very fast adjustment phase is characterized by a very rapid increase in sulfate AOD over North Africa in response to European emissions with Asian emissions having no effect (Figs. 5a and 7a, b). During this phase, the changes in column integrated water vapor, as well as the atmospheric temperature and specific humidity over North Africa, are very small (Figs. $5 \mathrm{~b}$ and 6). However, there is an increase in high cloud cover in response to European emissions; this increase is not statistically significant in the area mean (Fig. 5f), but it is significant locally (not shown). European emissions lead to the increase in CDNC and the decrease in CDER (Figs. 3c,e). The resultant large number of small droplets leads to a decrease in precipitation efficiency and an increase in high cloud cover (e.g., Twomey 1977; Rosenfeld et al. 2008; Stevens and Feingold 2009; Tao et al. 2012).

The aerosol-radiation and aerosol-cloud interactions from European emissions lead to an increase in top-ofatmosphere (TOA) upward SW radiation (Fig. 5d) during the first 20 days. The increased high cloud cover leads to a decrease in outgoing longwave radiation (OLR) (Fig. 5e). Changes in atmospheric clear-sky SW absorption and LW clear-sky radiative cooling are very small. As a result, the decrease in surface SW and the increase in surface LW (Figs. 5g,h) are similar to those changes at the TOA. Thus, the reduction in surface SW radiation cools the surface, only part of which is compensated by an increase in downward LW from the increase in cloud cover. The changes in turbulent heat fluxes are small (Fig. 5i), and thus the surface cools and the net surface LW decreases. Accordingly, European sulfur dioxide emissions lead to changes in cloud properties and surface energy on the time scale of weeks. However, these changes are relatively small and do not induce significant changes in SAT, the Saharan heat low, or the WAM circulation, and therefore Sahel precipitation, on this time scale (Figs. 5j-1).

Asian sulfur dioxide emissions do not affect the sulfate burden (Fig. 3b) or sulfate AOD (Figs. 5a and 7b) over North Africa during the first 20 days. As a result, the changes in upward SW radiation at TOA and OLR (Figs. 5d,e) and surface SW and LW radiation (Figs. 5g, h) are also small. Thus there is hardly any change in SAT over North Africa, or in the Saharan heat low, the WAM circulation, or Sahel precipitation in this initial phase (Figs. 5j-1).

\section{b. Second phase and time mean response}

As illustrated in Figs. 5b and 5c, a rapid decrease in column integrated water vapor and water vapor transport convergence in response to both European and Asian emissions occurs from days 21 to 30 . During this transition phase there are important changes in the surface and TOA energy budgets over North Africa, which are illustrated in Fig. 8. 
(a) Sulphate AOD at 0.55 um

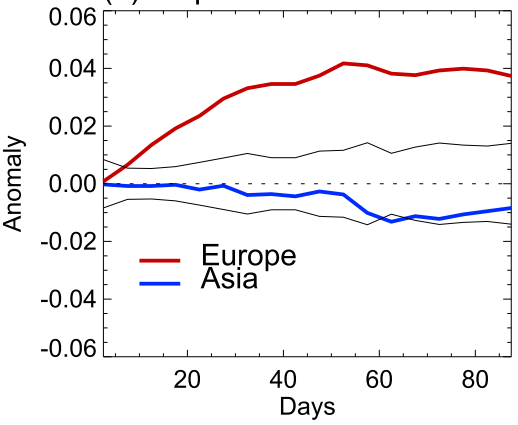

(d) TOA upward SW

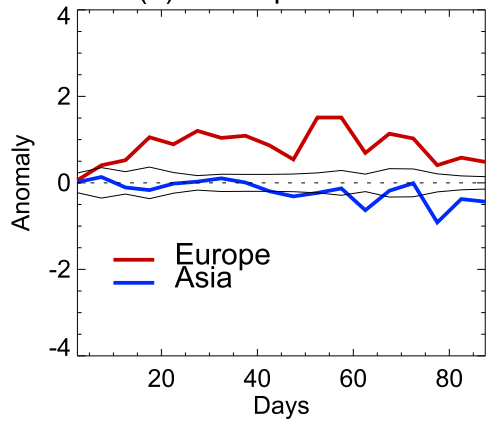

(g) Surface SW

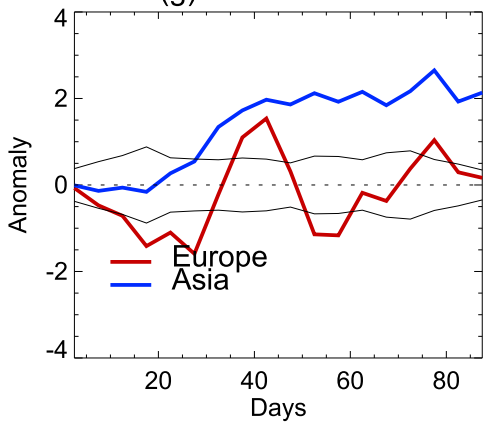

(j) SAT

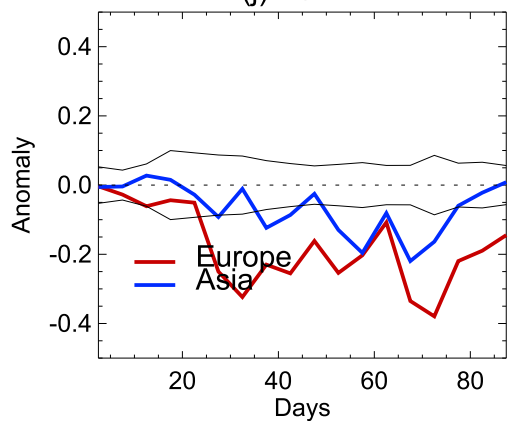

(b) Water vapor

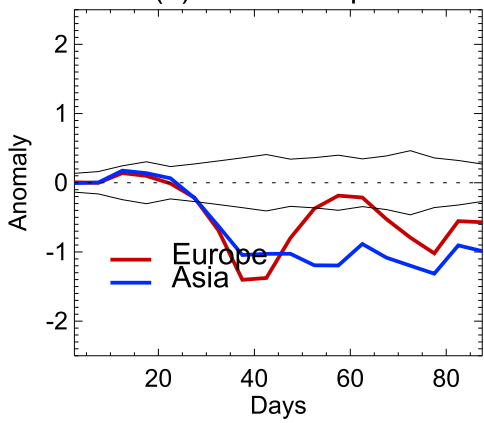

(e) OLR

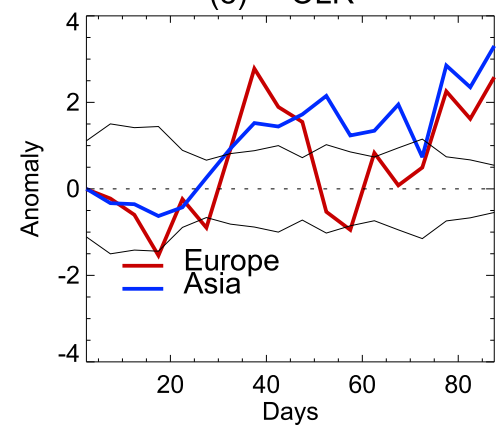

(h) Surface LW

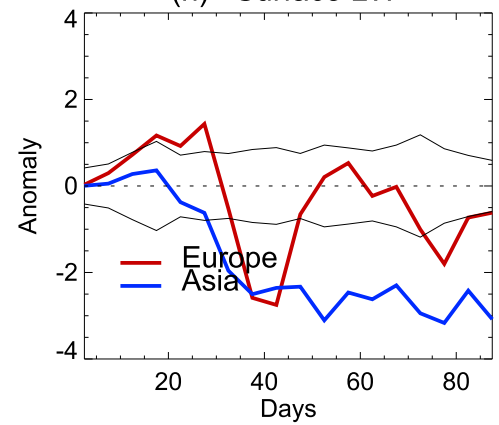

(k) SLP

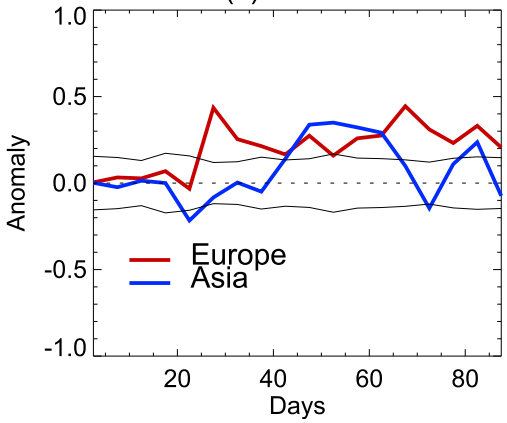

(c) Moisture convergence

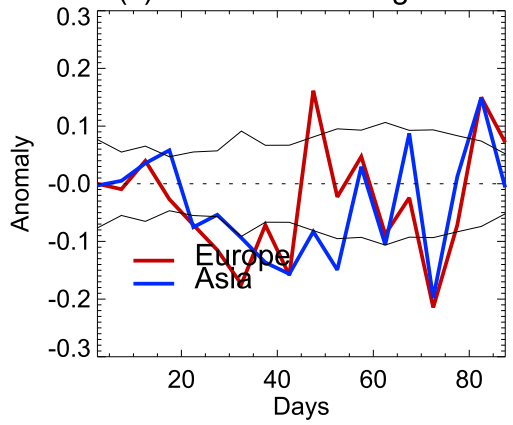

(f) High cloud

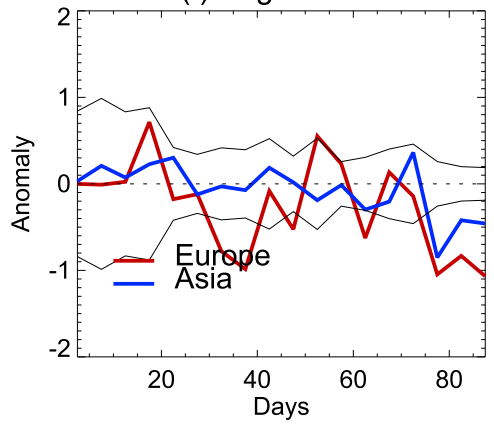

(i) Sensible+latent heat flux

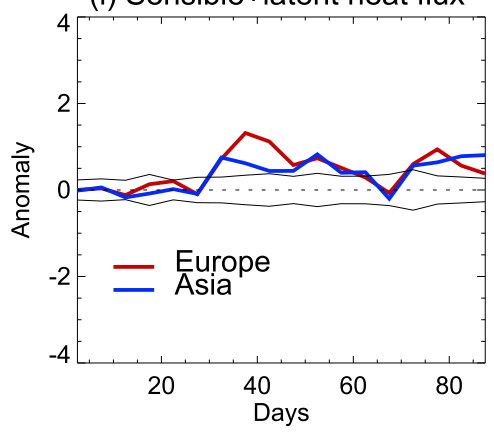

(I) Precipitation (5-20N, 20W-35E)

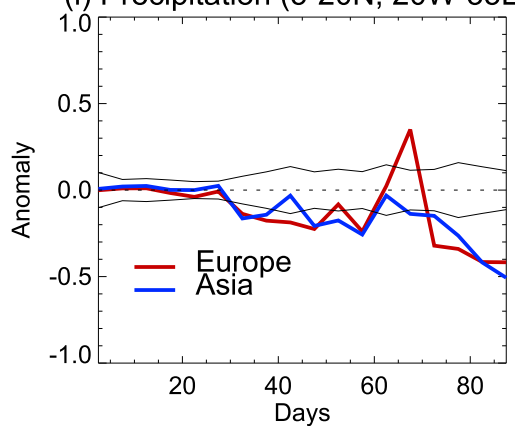

FIG. 5. The time evolutions of 5-day averaged ensemble mean changes over North Africa $\left(15^{\circ}-30^{\circ} \mathrm{N}, 20^{\circ} \mathrm{W}-35^{\circ} \mathrm{E}\right)$ induced by European and Asian sulfur dioxide emissions in JJA. (a) Sulfate AOD at $0.55 \mu \mathrm{m}$, (b) column integrated water vapor $\left(\mathrm{kg} \mathrm{m}^{-2}\right)$, (c) water vapor transport convergence $\left(\mathrm{kg} \mathrm{m}^{-2} \mathrm{day}^{-1}\right)$, (d) top of atmosphere (TOA) upward shortwave radiation (SW), (e) outgoing longwave radiation (OLR), (f) high cloud cover (\%), (g) surface SW, (h) surface LW, (i) surface sensible and latent heat flux, (j) surface air temperature (SAT, $\left.{ }^{\circ} \mathrm{C}\right)$, (k) SLP $(\mathrm{hPa})$, and (l) precipitation $\left(\mathrm{mm} \mathrm{day}^{-1}\right)$ over the Sahel $\left(5^{\circ}-20^{\circ} \mathrm{N}, 20^{\circ} \mathrm{W}-35^{\circ} \mathrm{E}\right)$. Radiation and flux are in $\mathrm{W} \mathrm{m}{ }^{-2}$ and positive values mean downward for surface radiation and flux changes. The thin lines show the $N^{-1 / 2}$ of internal standard deviation in the CONTROL experiment with the number of integrations $N=30$. 
(a) Temperature (Europe)

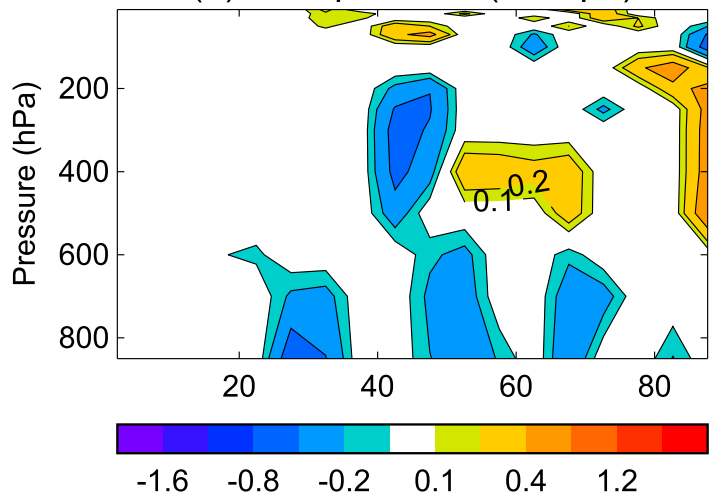

(c) Humidity \% (Europe)

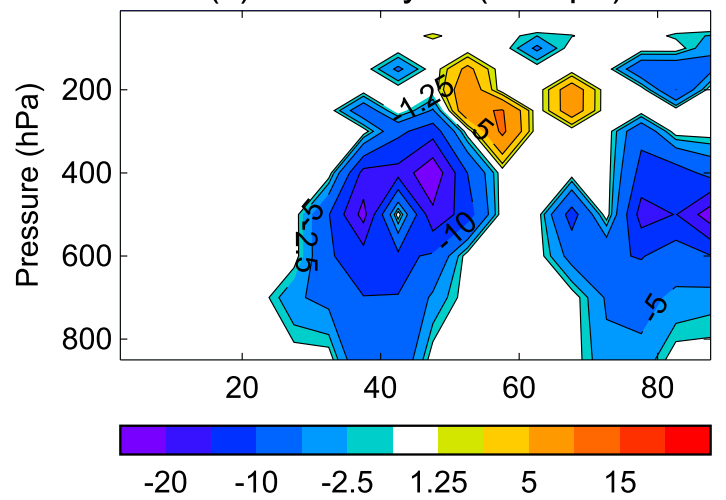

(b) Temperature (Asia)

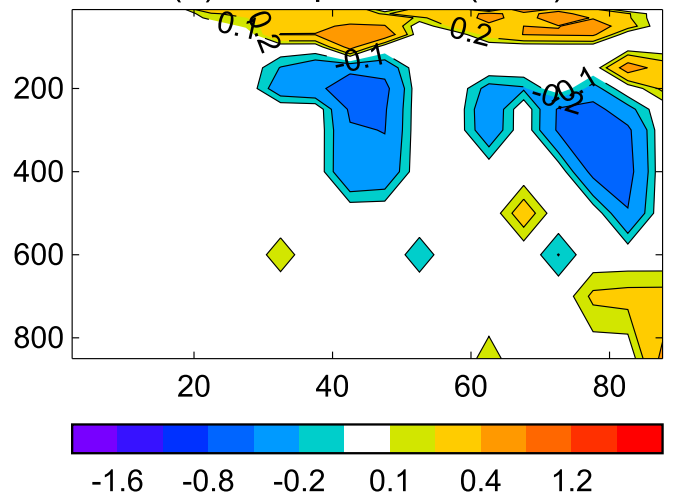

(d) Humidity \% (Asia)

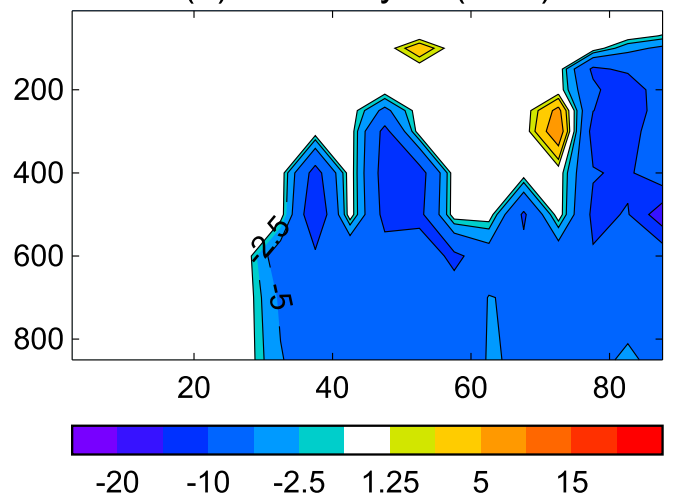

FIG. 6. The time evolutions of 5-day averaged ensemble mean changes with height over North Africa $\left(15^{\circ}-30^{\circ} \mathrm{N}\right.$, $20^{\circ} \mathrm{W}-35^{\circ} \mathrm{E}$ ) induced by (a),(c) European and (b),(d) Asian sulfur dioxide emissions in JJA for (top) temperature $\left({ }^{\circ} \mathrm{C}\right)$ and (bottom) percentage changes in specific humidity relative to the CONTROL experiment $(\%)$. Only changes that are statistically significant at the $90 \%$ confidence level using a two-tailed Student's $t$ test are shown.

In response to European emissions, the TOA energy budget in the transition phase is characterized by a decrease in clear-sky SW owing to aerosol scattering and absorption that is partially offset by a decrease in clear-sky

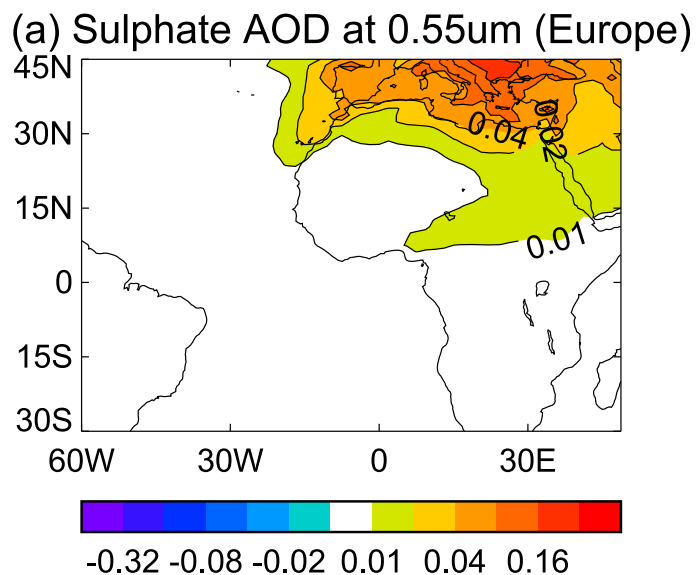

OLR owing to surface and tropospheric cooling (Fig. 6), with changes in SW and LW cloud radiative effect (CRE) being small (Fig. 8a). The change in surface energy input is characterized by a decrease in surface SW

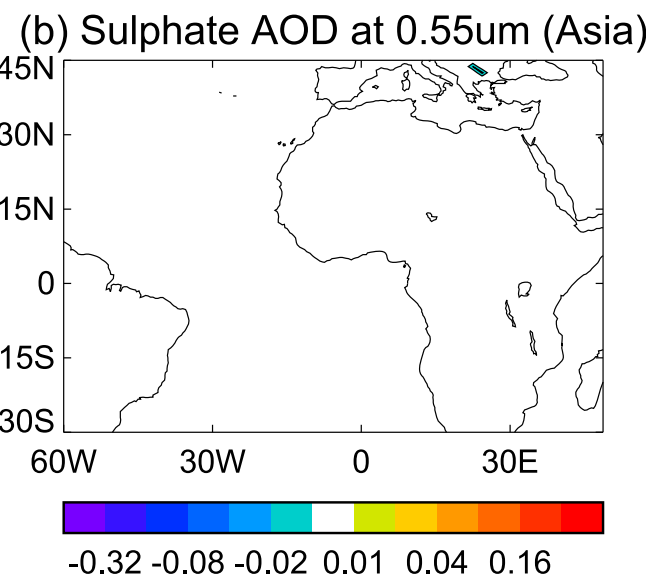

FIG. 7. Mean changes of sulfate AOD at $0.55 \mu \mathrm{m}$ (days 1-20 mean) in response to (a) European and (b) Asian sulfur dioxide emissions. Only changes that are statistically significant at the $90 \%$ confidence level using a two-tailed Student's $t$ test are shown. 
(a) Mean values at TOA for days 21 to 30

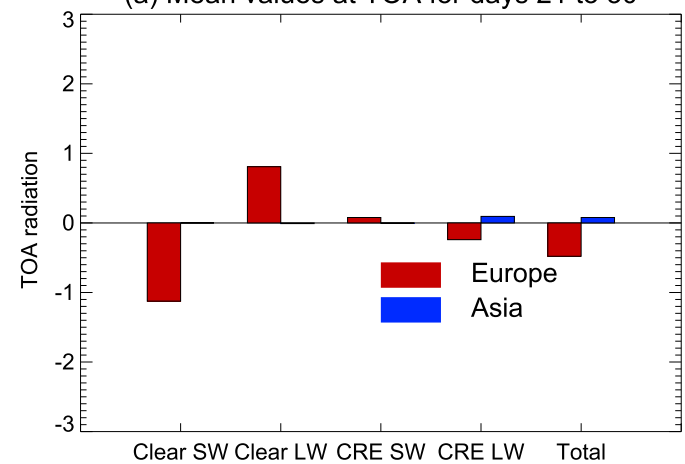

(c) Mean values at surface for days 21 to 30

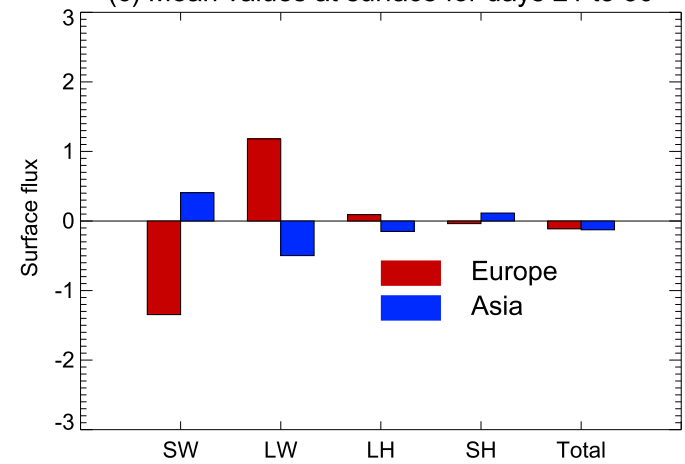

(b) Mean values at TOA for days 41 to 90

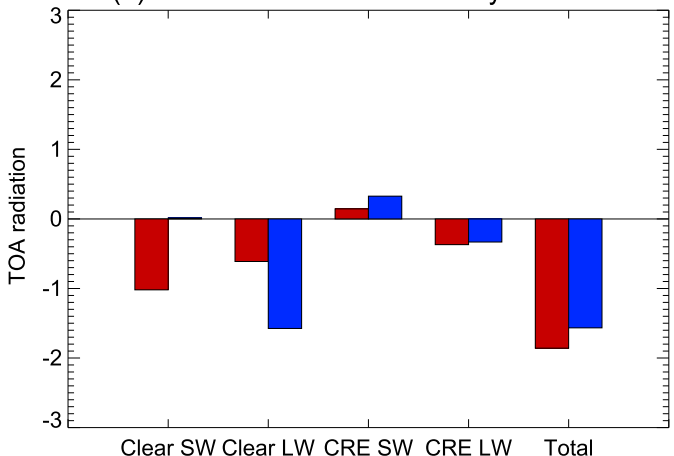

(d) Mean values at surface for days 41 to 90

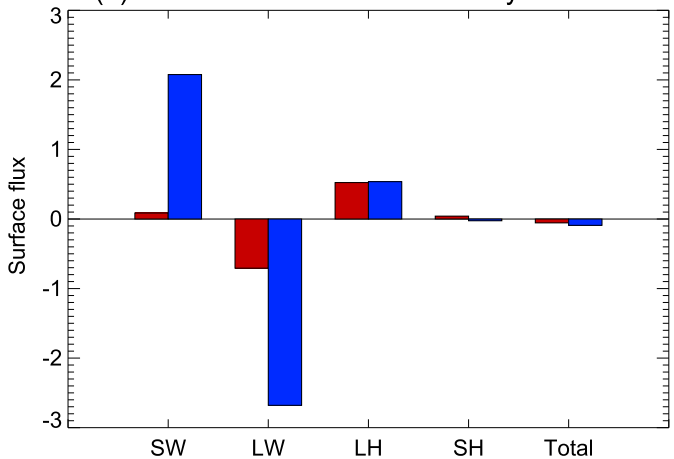

FIG. 8. Time averaged changes in (a),(b) TOA and (c),(d) surface energy over North Africa $\left(15^{\circ}-30^{\circ} \mathrm{N}, 20^{\circ} \mathrm{W}-\right.$ $35^{\circ} \mathrm{E}$ ) for days (left) 21-30 and (right) 41-90. Changes in TOA are clear-sky shortwave (Clear SW), clear-sky longwave (Clear LW), cloud radiative effect SW (CRE SW), CRE LW, and TOA total. Changes at surface are for shortwave (SW) and longwave (LW) radiation, latent heat flux (LH), surface sensible heat flux (SH), and surface total energy (Total). Radiation and flux $\left(\mathrm{W} \mathrm{m}^{-2}\right)$ are positive downward.

radiation that cools the surface, leading to a decrease in the net surface LW radiation, with changes in the turbulent heat fluxes being small (Fig. 8c).

In contrast, in response to Asian emissions, anomalies in TOA SW and LW fluxes are very small in the transition phase (Fig. 8a). At the surface, a decrease in net LW radiation due to drying and cooling in the troposphere (Fig. 6) is partially offset by an increase in surface downward SW radiation due to drying in the troposphere. The net change in turbulent heat fluxes is again small, resulting in an overall small net cooling. The processes responsible for drying in the troposphere will be discussed in section $4 b(2)$.

As indicated in Fig. 5a, the change in sulfate AOD in response to European sulfur dioxide emissions reaches values close to the equilibrium value during the second phase (after day 30). Responses to both European and Asian emissions during this phase are characterized by significant changes in the local hydrological cycle, column integrated water vapor, cloud, and lapse rate over North Africa (Figs. 5 and 6), and in atmospheric circulation. These changes lead to substantial changes in the
TOA and surface energy budgets (Figs. 5 and 8b,d), in comparison with the responses seen during the fast adjustment phase (up to 3 weeks) and the transition period of days 21-30 (Figs. 8a,c).

Because of large magnitudes of the responses during the second phase, the seasonal mean changes are dominated by this phase. Therefore, we focus next on understanding the detailed mechanisms responsible for the changes during the second phase.

\section{1) RESPONSES TO EUROPEAN EMISSIONS}

The spatial patterns of time mean changes of some key variables for days 41-90 induced by European sulfur dioxide emissions are illustrated in Fig. 9. The changes in area-averaged energy budget over North Africa at TOA and surface are shown in Figs. $8 \mathrm{~b}$ and $8 \mathrm{~d}$ with some areaaveraged variables being given in Table 3 . The pattern in sulfate AOD increase during this phase (Fig. 9a) is similar to that seen during the fast adjustment phase (Fig. 7a), but with larger magnitude. The scattering by sulfate aerosols and the increase in cloud albedo related to the decrease in cloud droplet effective radius lead to 
(a) Sulphate AOD at $0.55 \mathrm{um}$

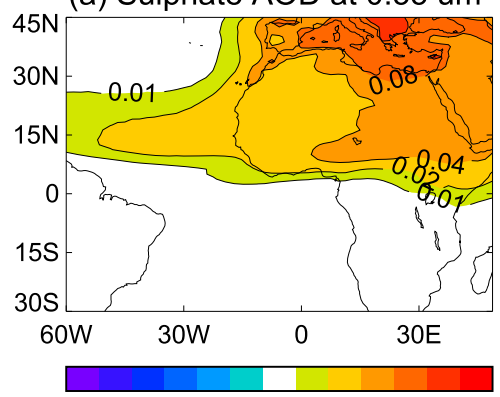

$\begin{array}{llllll}-0.32 & -0.08 & -0.02 & 0.01 & 0.04 & 0.16\end{array}$

(d) Clear sky OLR

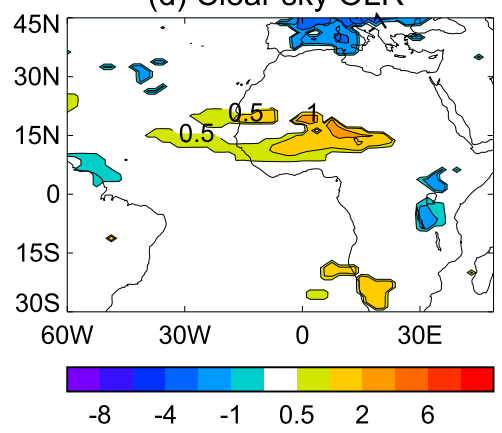

(g) High cloud

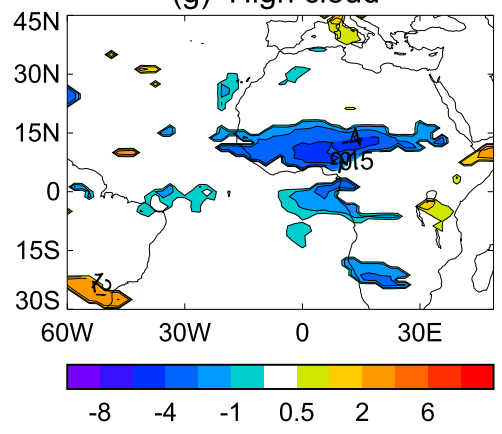

(j) Moisture transport

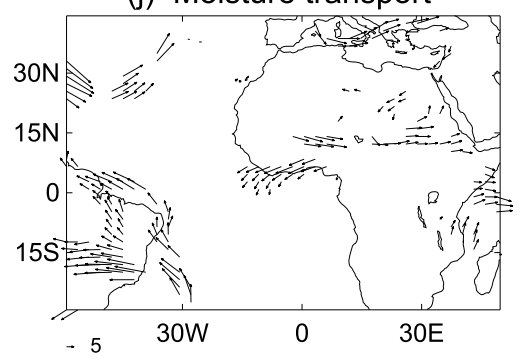

(b) water vapor

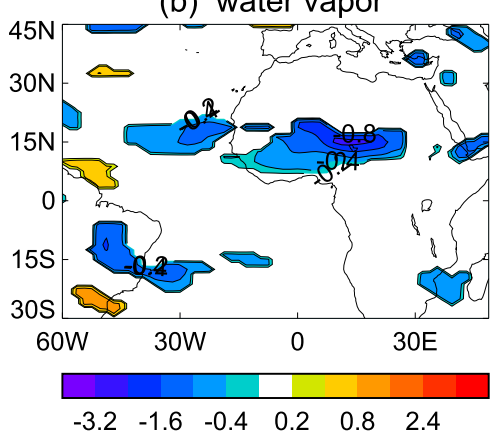

(e) Surface SW

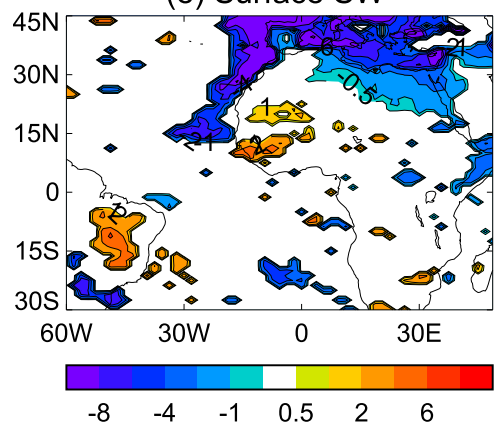

(h) SAT

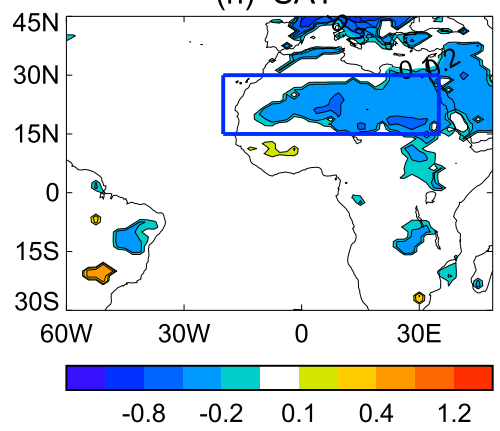

(k) Moisture convegence

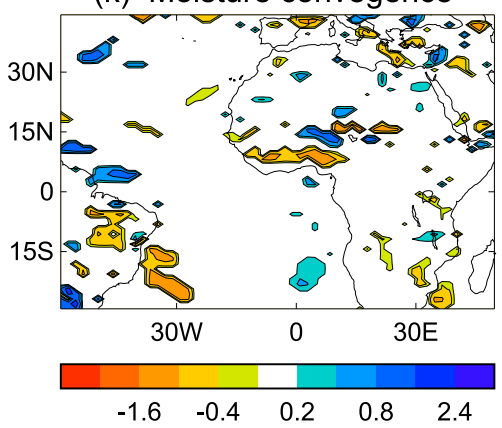

(c) TOA clear sky upward SW

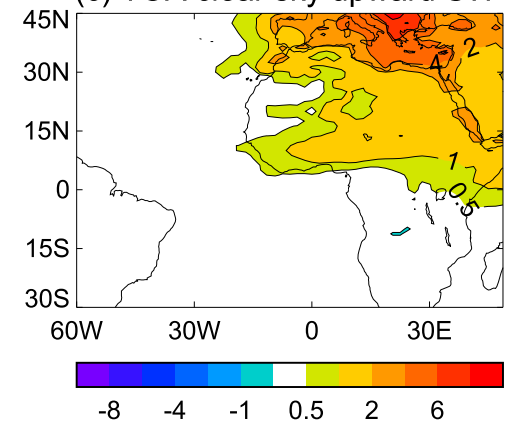

(f) Surface LW

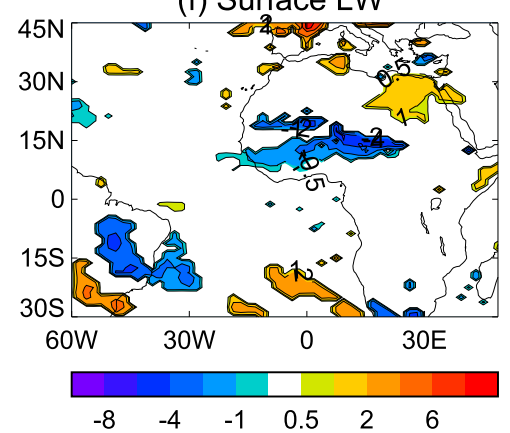

(i) SLP and $850 \mathrm{hPa}$ wind

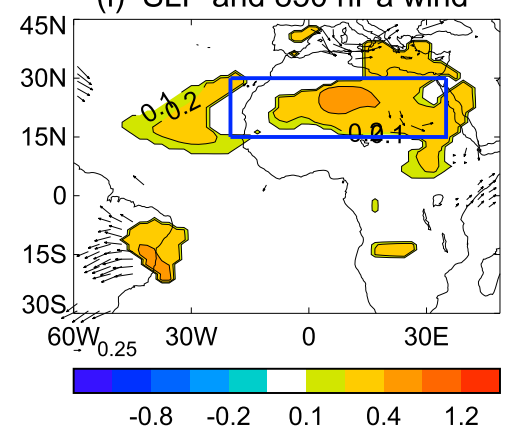

(I) precipitation

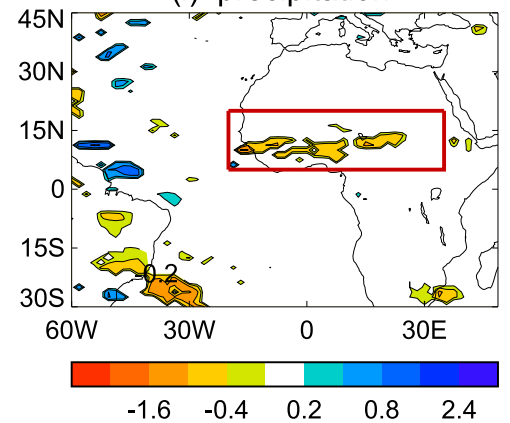

FIG. 9. Mean anomalies (days 41-90 mean) in response to European emissions. (a) Sulfate AOD at $0.55 \mu \mathrm{m}$, (b) column integrated water vapor $\left(\mathrm{kg} \mathrm{m}^{-2}\right)$, (c) TOA clear-sky upward SW, (d) clear-sky OLR, (e) surface SW, (f) surface LW, (g) high cloud cover (\%), (h) surface air temperature $\left(\mathrm{SAT} ;{ }^{\circ} \mathrm{C}\right)$, (i) SLP $(\mathrm{hPa})$ and $850-\mathrm{hPa}$ wind $\left(\mathrm{m} \mathrm{s}^{-1}\right)$, (j) vertically integrated water vapor transport $\left(\mathrm{kg} \mathrm{m}^{-1} \mathrm{~s}^{-1}\right),(\mathrm{k})$ convergence of vertically integrated water vapor transport $\left(\mathrm{kg} \mathrm{m}^{-2}\right.$ day $\left.^{-1}\right)$, and (l) precipitation $\left(\mathrm{mm} \mathrm{day}^{-1}\right)$. Radiation is in $\mathrm{W} \mathrm{m}^{-2}$ and positive values mean downward for surface radiation changes. Only changes that are statistically significant at the $90 \%$ confidence level using a two-tailed Student's $t$ test are shown. 
TABLE 3. Area-averaged responses for various variables in days $41-90$ over North Africa $\left(15^{\circ}-30^{\circ} \mathrm{N}, 20^{\circ} \mathrm{W}-35^{\circ} \mathrm{E}\right.$; land only). Positive values mean downward for radiation and flux changes.

\begin{tabular}{|c|c|c|}
\hline & $\begin{array}{l}\text { European } \\
\text { impact }\end{array}$ & $\begin{array}{l}\text { Asian } \\
\text { impact }\end{array}$ \\
\hline Sulfate AOD at $0.55 \mu \mathrm{m}$ & 0.039 & -0.009 \\
\hline $\begin{array}{l}\text { Column integrated water vapor } \\
\left(\mathrm{kg} \mathrm{m}^{-2}\right)\end{array}$ & -0.64 & -1.08 \\
\hline High cloud cover $(\%)$ & -0.34 & -0.18 \\
\hline Medium cloud cover & -0.07 & -0.26 \\
\hline Low cloud cover & -0.02 & 0.01 \\
\hline Surface latent heat $\left(\mathrm{W} \mathrm{m}^{-2}\right)$ & 0.52 & 0.54 \\
\hline Surface sensible heat $\left(\mathrm{W} \mathrm{m}^{-2}\right)$ & 0.04 & -0.03 \\
\hline \multirow[t]{2}{*}{ Surface total flux $\left(\mathrm{W} \mathrm{m}^{-2}\right)$} & -0.06 & -0.09 \\
\hline & SW, LW & SW, LW \\
\hline $\mathrm{TOA}\left(\mathrm{W} \mathrm{m}^{-2}\right)$ & $-0.88,-0.98$ & $0.34,-1.91$ \\
\hline TOA clear sky $\left(\mathrm{W} \mathrm{m}^{-2}\right)$ & $-1.02,-0.61$ & $0.01,-1.57$ \\
\hline $\begin{array}{l}\text { Cloud radiative effect } \\
(\mathrm{CRE})\left(\mathrm{W} \mathrm{m}^{-2}\right)\end{array}$ & $0.14,-0.37$ & $0.33,-0.34$ \\
\hline Surface $\left(\mathrm{W} \mathrm{m}^{-2}\right)$ & $0.09,-0.71$ & $2.08,-2.68$ \\
\hline Surface clear sky $\left(\mathrm{W} \mathrm{m}^{-2}\right)$ & $-0.06,-0.62$ & $1.74,-2.42$ \\
\hline Atm: TOA-Surface $\left(\mathrm{W} \mathrm{m}^{-2}\right)$ & $-0.96,-0.27$ & $-1.74,0.77$ \\
\hline $\begin{array}{l}\text { Atm: TOA-Surface clear } \\
\text { sky }\left(\mathrm{W} \mathrm{m}^{-2}\right)\end{array}$ & $-0.96,0.01$ & $-1.73,0.85$ \\
\hline
\end{tabular}

an increased TOA clear-sky upward SW radiation by about $0.5-1.5 \mathrm{~W} \mathrm{~m}^{-2}$ over North Africa (Fig. 9c) with an area mean net change of $-1.0 \mathrm{~W} \mathrm{~m}^{-2}$ (Fig. 8b, Table 3 ).

Another important change during this phase is the previously mentioned decrease in column integrated water vapor (Figs. 5b and 9b; Table 3) over North Africa and the tropical North Atlantic (Fig. 9b). The decrease over North Africa is related to the decrease in vertically integrated water vapor transport convergence (Fig. 5c). The reduction in water vapor enhances radiative cooling to space and therefore results in an increase in clear-sky OLR (negative change in clear-sky LW radiation) (Figs. 8d and 9d; Table 3 ), in contrast to the transition phase (cf. Figs. $8 \mathrm{a}$ and $8 b$ ). The cloud response during the second phase shows a decrease in high cloud cover $(\sim 1 \%-3 \%)$ over the Sahel (Fig. $9 \mathrm{~g})$. Consistent with the decrease in high cloud cover is a positive SW CRE and negative LW CRE that partially offset the change in clear-sky upward SW at TOA and enhance the change in clear-sky OLR (Fig. 8b, Table 3).

The reduction in water vapor is also associated with a decrease in SW absorption by the atmosphere (Table 3 ), so the anomaly in surface SW radiation in the second phase is very small, even though the anomaly in TOA SW radiation is substantial and very similar to that seen in the transition phase. The change in net upward surface LW radiation is very similar to that in the TOA (cf. Figs. 8c and 8d) but has opposite sign to that found in the transition phase (Fig. 8c) because reduced surface emission due to the cooler surface temperature is more than offset by a larger decrease in downward LW emitted by the atmosphere, due to the cooling and drying of the troposphere. The change in surface sensible heat flux is small over North Africa (Table 3, Fig. $8 d$ ), but there are significant decreases in upward latent heat flux in the south of the region (not shown) associated with reduced soil moisture availability related to precipitation decrease (Table 3, Fig. 91). These changes in surface and TOA energy budgets indicate the important role of the feedbacks associated with changes in cloud and water vapor during the second phase.

The cold surface (Fig. 9h) leads to an increase in SLP (Fig. 9i) over North Africa. Associated with this SLP change is an anomalous anticyclonic circulation in the lower troposphere (Fig. 9i), corresponding to a weakening of the trade winds over the tropical North Atlantic and a weakening WAM circulation. This in turn induces anomalous vertically integrated water vapor transport (Fig. 9j) with anomalous divergence over the Sahel (Fig. 9k), associated with a reduction in precipitation there (Fig. 9l).

European emissions affect climate not only over the Atlantic sector, but also remotely over the globe. The teleconnection induced by European emissions is illustrated in Fig. 10 which shows the velocity potential at $250 \mathrm{hPa}$. The main features during the transition period of days 21-30 in response to European emissions are the anomalous upper tropospheric divergence over the western tropical Atlantic and anomalous convergence over Africa and the western Indian Ocean (Fig. 10a) with some small-scale features over the tropical Pacific. Associated with these anomalous divergent circulations is increased precipitation over the Caribbean Sea and decreased precipitation over the eastern tropical Atlantic (not shown). Meanwhile, the anomalous upper tropospheric convergence over Africa is associated with lower tropospheric divergence (not shown), which in turn is responsible for the reduced moisture transport convergence (Fig. 5c), leading to the decrease in column integrated water vapor (Fig. $5 b$ and $6 c$ ).

The pattern of anomalous divergent circulation in the second phase shows some evolution from the transition phase (Fig. 10c). The pattern over the Atlantic and Africa is consistent with an east-west dipole pattern in the tropical precipitation in this region (Fig. 91). Meanwhile there is anomalous upper tropospheric divergence (associated with increased precipitation, not shown) in the western tropical Pacific, indicating an Atlantic-Pacific connection (e.g., Wang 2006; Kucharski et al. 2009; Dong and Lu 2013). However, detailed study of the remote response to European emissions over the Pacific is beyond the scope of this paper, and will be investigated in another study. 
(a) $250 \mathrm{hPa}$ VP (day 21 to 30 ) (Europe)

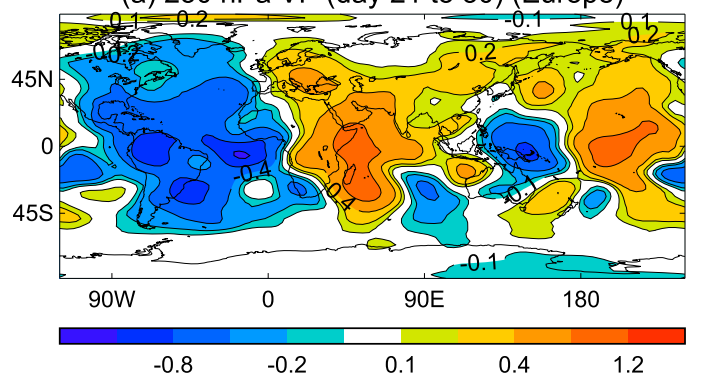

(c) $250 \mathrm{hPa}$ VP (day 41 to 90) (Europe)

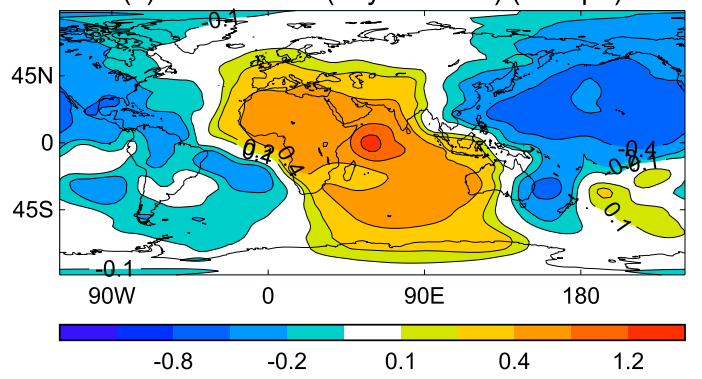

(b) $250 \mathrm{hPa}$ VP (day 21 to 30 ) (Asia)

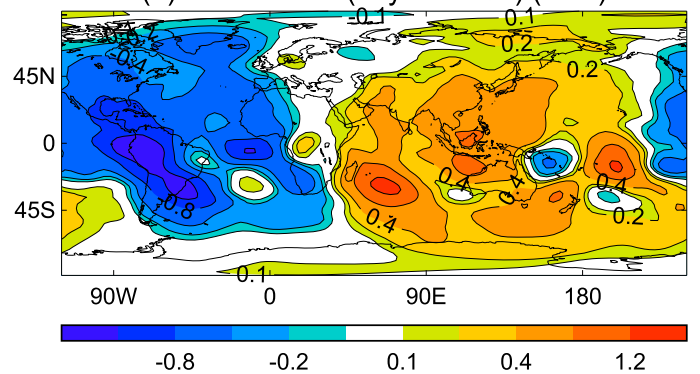

(d) $250 \mathrm{hPa}$ VP (day 41 to 90) (Asia)

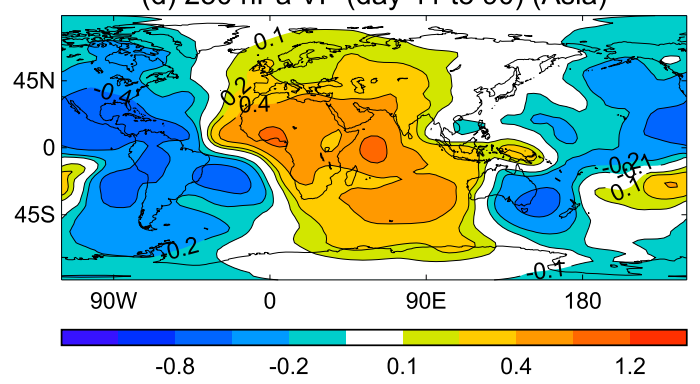

FIG. 10. The spatial patterns of the changes in velocity potential $\left(10^{6} \mathrm{~m}^{2} \mathrm{~s}^{-1}\right)$ at $250 \mathrm{hPa}$ in response to (a),(c) European and (b),(d) Asian emissions, respectively, for averaged values of days (top) 21-30 and (bottom) 41-90.

In summary, in the first phase the responses to European emissions are predominantly through the aerosolradiation and aerosol-cloud interactions caused by the direct impact of European emissions on the sulfate aerosol burden over North Africa. It is the resulting decrease in the net surface SW radiation that leads to surface cooling during this phase. In the second phase, however, there are important feedbacks-associated with the decrease in column integrated water vapor and changes in clouds, both related to the change in WAM - that lead to quite different surface and TOA energy budgets.

\section{2) Responses to Asian emissions}

The spatial patterns of time mean changes of some key variables for days 41-90 induced by Asian sulfur dioxide emissions are illustrated in Fig. 11 (see also Table 3 and Figs. 8 b, d for area mean changes). In comparison with the TOA and surface energy budgets during days 21-30 (Figs. 8a,c), the important differences are the large increase in clear-sky OLR (negative change in clear-sky LW at TOA) (Fig. 8b), the large decrease in surface net $\mathrm{LW}$ radiation, and the large increase in surface SW radiation (Fig. 8d). The large LW changes at both TOA and surface are associated with significant decreases in column integrated water vapor (Fig. 11a) over North Africa and the tropical North Atlantic. The reduction in water vapor enhances radiative cooling to space, and therefore results in an increase in clear-sky OLR (Figs. 8b and 11b; Table 3). However, decreased water vapor concentration also reduces the LW radiative cooling of the atmosphere to the surface, leading to a decrease in downward LW radiation at the surface (Table 3, Fig. 8d), and therefore a decrease in net downward LW radiation (Figs. 8d and 11c; Table 3). Meanwhile, the cooling of the atmosphere decreases the clear-sky LW cooling by decreasing the emission to space and, to a greater extent, to the surface (e.g., Allan 2006). The water vapor feedback may also contribute to a strengthening in the upper tropospheric cooling as demonstrated by previous studies (Gettelman and Fu 2008; Minschwaner et al. 2006). As a result, the decreased water vapor concentration and large upper tropospheric cooling (Figs. 6b,e) reduce the LW radiative cooling of the atmosphere to the surface, leading to larger decrease in surface LW radiation than that at the TOA. The change in TOA clear-sky SW is negligible (Table 3) since Asian emissions do not change the sulfate burden (Fig. 3b), sulfate AOD (Fig. 5a), or CDNC and CDER (Figs. 3d,f) over North Africa. However, the decreased water vapor concentration leads to a reduction in atmospheric heating by SW absorption (e.g., Mitchell et al. 1987), and this is associated with an increase in surface clear-sky downward, and therefore surface net downward, SW radiation (Figs. 8d and 11d; Table 3). The decrease in high cloud (Fig. 11g) leads to a cloud radiative effect LW cooling and SW warming, but these changes are quite small (Table 3; Fig. 8b).

The latent heat flux over the Sahel shows a reduction (Figs. 8e and 11e) related to surface feedbacks since the 
(a) Water vapor

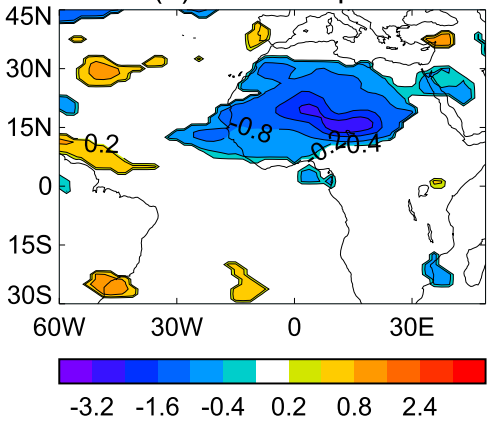

(d) Surface SW

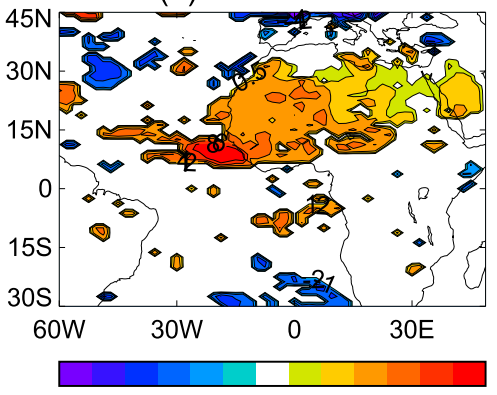

$\begin{array}{llllll}-8 & -4 & -1 & 0.5 & 2 & 6\end{array}$

(g) High cloud

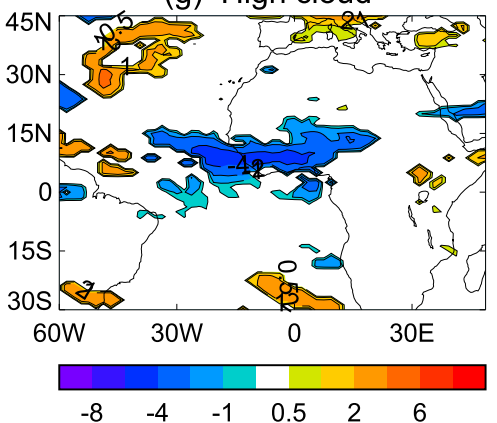

(j) Moisture transport

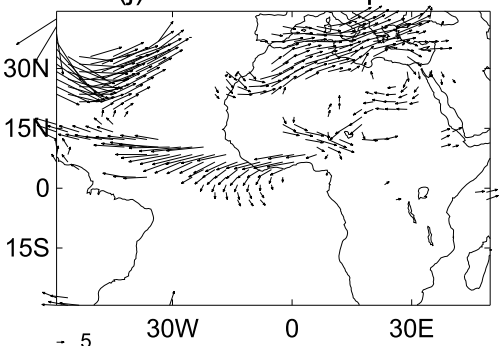

(b) Clear sky OLR

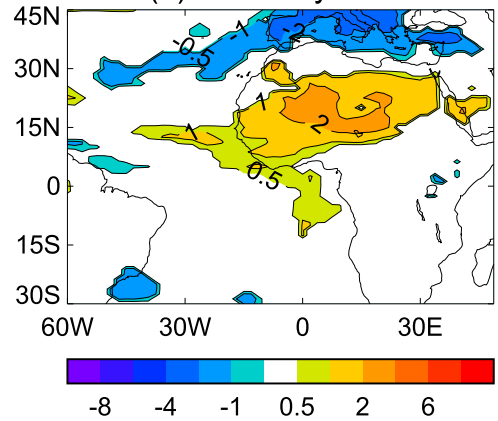

(e) Latent heat flux

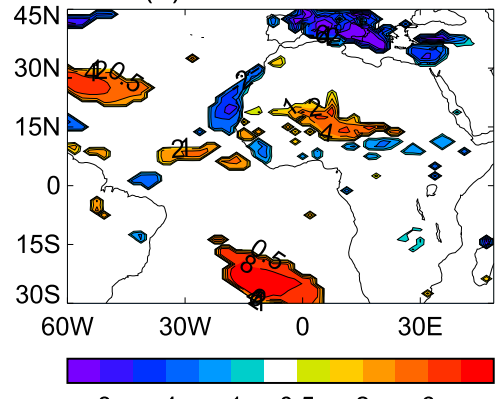

(h) SAT

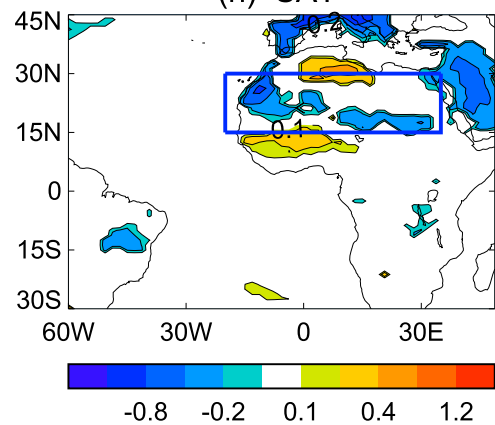

(k) Moisture convegence

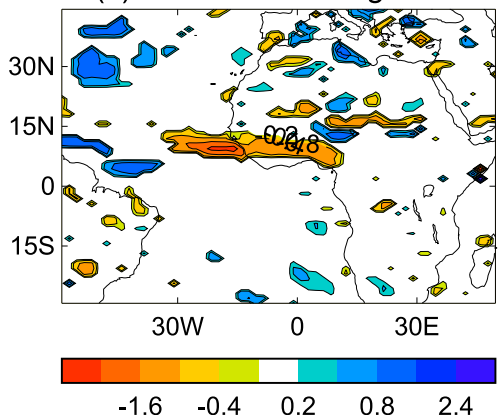

(c) Surface LW

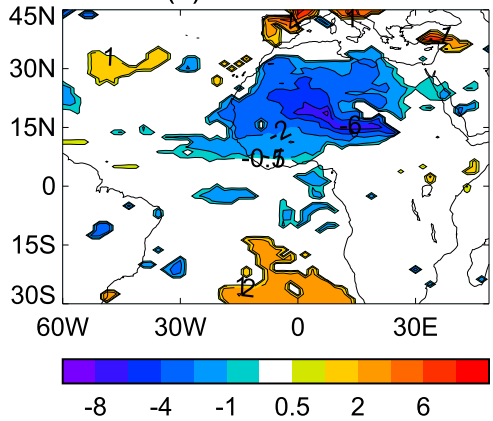

(f) Sensible heat flux

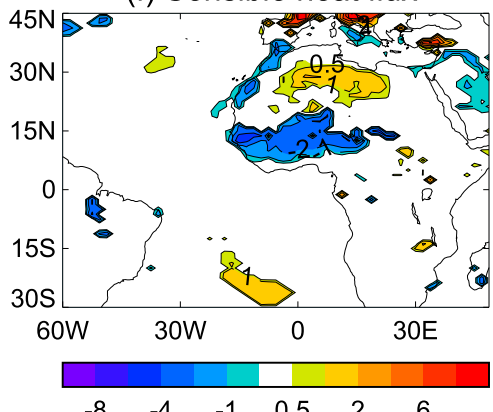

(i) SLP and $850 \mathrm{hPa}$ wind

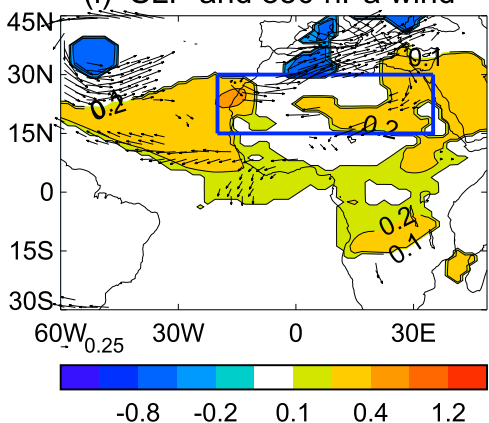

(I) precipitation

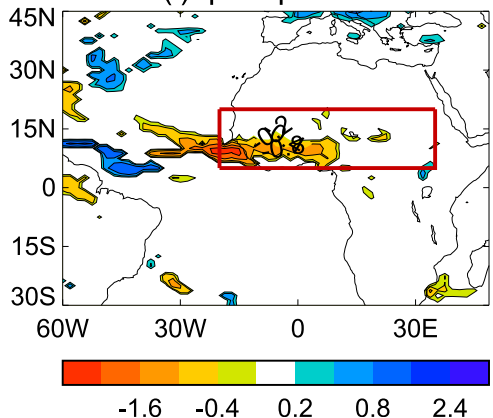

FIG. 11. Mean anomalies (days 41-90 mean) in response to Asian emissions. (a) Column integrated water vapor (kg m ${ }^{-2}$ ), (b) clear sky OLR, (c) surface LW, (d) surface SW, (e) surface latent heat flux, (f) surface sensible heat flux, (g) high cloud cover (\%), (h) SAT $\left({ }^{\circ} \mathrm{C}\right)$, (i) SLP $(\mathrm{hPa})$ and $850-\mathrm{hPa}$ wind $\left(\mathrm{m} \mathrm{s}^{-1}\right),(\mathrm{j})$ vertically integrated water vapor transport $\left(\mathrm{kg} \mathrm{m}^{-1} \mathrm{~s}^{-1}\right),(\mathrm{k})$ convergence of vertically integrated water vapor transport $\left(\mathrm{kg} \mathrm{m}^{-2} \mathrm{day}^{-1}\right)$, and (l) precipitation $\left(\mathrm{mm} \mathrm{day}^{-1}\right)$. Radiation and flux are in $\mathrm{W} \mathrm{m}^{-2}$ and positive values mean downward for surface radiation and flux changes. Only changes that are statistically significant at the $90 \%$ confidence level using a twotailed Student's $t$ test are shown. 
decreased precipitation induces drying of soil (not shown). The changes in upward sensible heat flux over North Africa show a dipole pattern with a reduction in the north and an increase over the Sahel (Fig. 11f) with little area mean change (Fig. 8d) being related to dipole pattern of SAT change (Fig. 11h). The decrease in surface LW (Fig. 11c) owing to the decrease in water vapor and tropospheric cooling just overwhelms the increase in surface SW radiation (Fig. 11d) and the decrease in surface $\mathrm{LH}$ flux (Fig. 11e) to give a negative net surface energy change (Fig. 8d; Table 3) and a modest cooling at the surface.

The cooling over North Africa is associated with an anomalous high SLP and anticyclonic circulation anomaly in the lower troposphere (Fig. 11i), corresponding to a weakening of the trade winds over the tropical North Atlantic and a weakening WAM circulation. This, in turn, is associated with anomalous vertically integrated moisture transport (Fig. 11j) with anomalous divergence over the Sahel (Fig. 11k), resulting a reduction in precipitation there (Fig. 111).

Figures $5 \mathrm{~b}$ and $6 \mathrm{~d}$ show that the rapid decrease in water vapor content occurs from day 21 to day 30, and associated with this decrease in the water vapor is the rapid cooling in the upper troposphere (Fig. 6b). It is the decrease in water vapor transport convergence (Fig. $5 \mathrm{c}$ ) over North Africa that is responsible for the decrease in column integrated water vapor there, with the change in evaporation being small (not shown). The change in water vapor transport convergence is related to an adjustment of the tropical Walker circulation, illustrated in Figs. 10b and 10d. As in the response to European emissions, the pattern of circulation change in response to Asian emissions undergoes significant evolution between the transition phase and the second phase. Detailed analysis of this evolution is beyond the scope of this study, but an interesting finding is that the final pattern in the second phase shows notable similarities between the two experiments-in particular, anomalous convergence over the Indian Ocean and Africa and anomalous divergence of over the Americas, western Atlantic, and much of the Pacific Ocean. This similarity suggests the possibility of a preferred response of the tropical circulation to quite different perturbations. This preferred response involves the weakening of the WAM, associated with reductions in precipitation and cooling and drying over the Sahel. Interestingly, however, in spite of these dynamical and hydrological similarities, the anomalous energy budgets for the North African region, at both the TOA and surface, are quite different in the two experiments (Figs. 8b,d).

In summary, it is feedbacks associated with the decrease in column integrated water vapor over North Africa that are responsible for the weakened WAM and reduced Sahel rainfall in response to Asian emissions.
The large water vapor feedbacks over North Africa are likely to be related to the low climatological water vapor content in the region since absorption of LW radiation increases approximately with the logarithm of water vapor concentration and therefore it is the fractional change in water vapor concentration that governs its feedback strength (Randall et al. 2007). The important role of water vapor change in this study is in line with a recent study (Liu et al. 2014) that suggested a teleconnection between North Atlantic cooling and a weakened WAM through tropospheric cooling and drying.

\section{Conclusions}

In this study, we have investigated the impacts of regional sulfur dioxide emissions on Sahel summer (JJA) precipitation through its impacts on the atmosphere and the surface with an atmospheric general circulation model, excluding SST feedbacks. We examined the transient adjustment processes of the surface and troposphere when either European or Asian sulfur dioxide emissions are turned on suddenly. The adjustment processes can be grouped into two phases: 1) the fast adjustment phase of the atmosphere mainly related to the aerosol-radiation and aerosol-cloud interactions, without hydrological cycle changes and surface feedbacks (up to 3 weeks), and 2) the slower adjustment of the atmosphere and surface with significant hydrological cycle changes, nonlocal dynamical changes, and associated surface feedbacks (beyond 3 weeks). These processes are summarized schematically in Fig. 12.

- The fast response to European emissions involves a direct impact on the sulfate burden over North Africa, with immediate consequences for the SW energy budget. An increase in SW scattering leads to a decrease in surface SW radiation that favors surface cooling over North Africa. By contrast, the fast response to Asian emissions has no significant impact on the sulfate burden over North Africa. This response is initially local and involves changes in precipitation over Asia and the Maritime Continent (not shown), which leads to an adjustment of the Walker circulation. In response to both European and Asian emissions, changes over North Africa in SAT, SLP, and the hydrological cycle are very small during the first phase.

- The responses during the second phase, which dominate the seasonal mean (JJA) responses, are characterized by significant changes in the local hydrological cycle, water vapor, cloud, lapse rate, and atmospheric circulation over North Africa. Changes in all these variables are closely coupled. Surface cooling is associated with an increase in SLP, a weakened Saharan heat low, and a weakened WAM circulation, which is in turn related to 


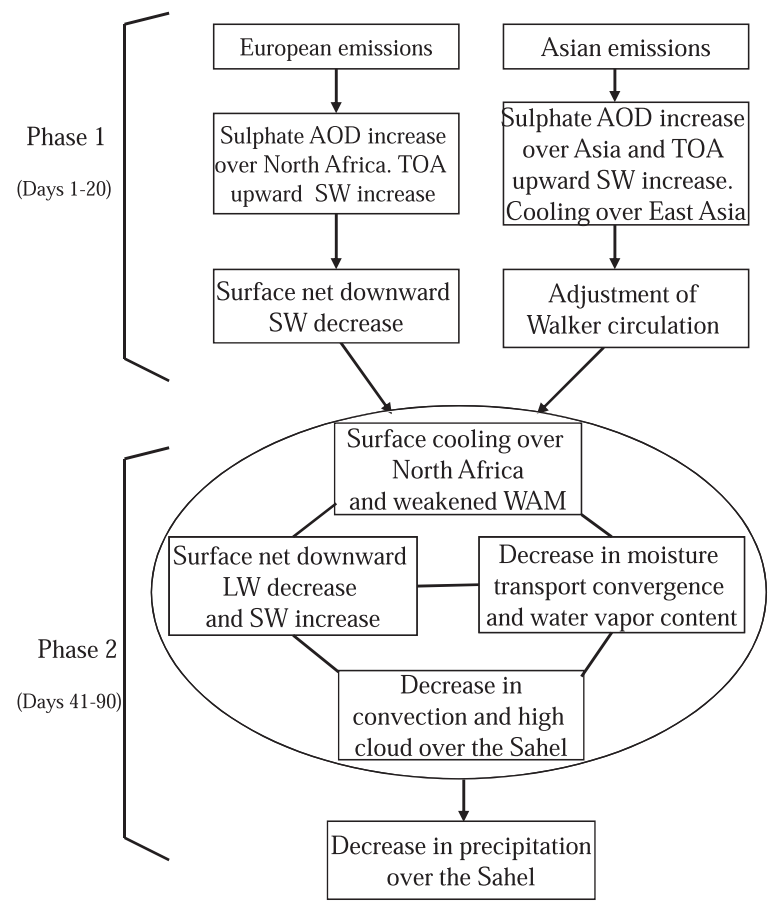

FIG. 12. Schematic diagram illustrating the major processes of the WAM and Sahel precipitation responses to European and Asian anthropogenic sulfur dioxide emissions.

a decrease in moisture convergence and a reduction in convection and precipitation. The decrease in convection is associated with a reduction in high cloud. These feedbacks lead to very different anomalous energy budgets at the top of the atmosphere (TOA) and surface in comparison to those found during the first phase. Cooling and drying of the troposphere over North Africa plays a particularly important role in the energy budgets in response to both European and Asian emissions.

- The responses to European and Asian emissions during the second phase exhibit similar large-scale patterns of anomalous atmospheric circulation and hydrological variables, suggesting a preferred response even in the absence of SST feedbacks. However, the anomalous energy budgets for the North African region, at both the TOA and surface, are quite different in the two experiments (Figs. 8b,d). This finding highlights the importance of dynamics over thermodynamics for understanding regional climate change.

Our experiments were deliberately simplified to exclude feedbacks involving changes in sea surface temperatures (SSTs). Nevertheless it is interesting that the responses we found show some similarities to observed multidecadal change in precipitation across the 1960s over the Sahel (Fig. 2e), supporting the idea that sulfate aerosol emissions contributed to the observed decline in Sahel precipitation from the 1940s-50s to the 1970s-80s (e.g., Held et al. 2005; Ackerley et al. 2011: Chang et al. 2011; Booth et al. 2012; Haywood et al. 2013; Hwang et al. 2013). Quantitatively, the reductions in Sahel precipitation simulated in our experiments are around $20 \%$ of the observed change $\left(-0.48 \mathrm{~mm} \mathrm{day}^{-1}\right)$ and the pattern is somewhat different. It is highly likely that SST feedbacks would both amplify the responses and modify the pattern: as discussed in the introduction, several studies have suggested that sulfate aerosol emissions caused a cooling of Northern Hemisphere SST relative to Southern Hemisphere SST, and a consequent southward shift of the ITCZ (Held et al. 2005; Ackerley et al. 2011; Chang et al. 2011; Booth et al. 2012; Haywood et al. 2013; Hwang et al. 2013). The SST feedbacks are expected to evolve on time scales of months to decades, longer than those considered in this study. Also vegetation and soil moisture feedbacks may evolve on longer time scales and are not fully addressed in this study. Understanding how these SST feedbacks modify the relatively fast processes that we have identified is an important area for future work. In addition, the experimental design employed in this study precludes investigating the full impact of aerosol emissions on premonsoon land surface conditions, which might affect our results. To investigate possible sensitivity to the premonsoon conditions we performed an additional set of experiments, each with 30 members, initialized on 1 May. These new experiments show similar seasonal mean changes in Sahel rainfall in response to a change in either European or Asian sulfur dioxide emissions (not shown), and therefore demonstrate that our major results and conclusions are not strongly sensitive to the premonsoon land surface conditions.

Acknowledgments. This work is supported by PAGODA project of the Changing Water Cycle programme of UK Natural Environment Research Council (NERC) under Grant NE/I006672/1 and the European Union's Seventh Framework Programme (FP7/2007-2013) under Grant Agreement 607085. BD and RTS are supported by the U.K. National Centre for Atmospheric ScienceClimate (NCAS-Climate) at the University of Reading. The authors thank three anonymous reviewers for their constructive comments on the early version of the paper.

\section{REFERENCES}

Ackerley, D., B. B. B. Booth, S. H. E. Knight, E. J. Highwood, D. J. Frame, M. R. Allen, and D. P. Rowell, 2011: Sensitivity of twentieth-century Sahel rainfall to sulfate aerosol and $\mathrm{CO}_{2}$ forcing. J. Climate, 24, 4999-5014, doi:10.1175/JCLI-D-11-00019.1.

Adler, R. F., and Coauthors, 2003: The version-2 Global Precipitation Climatology Project (GPCP) Monthly Precipitation Analysis (1979-present). J. Hydrometeor., 4, 1147-1167, doi:10.1175/ 1525-7541(2003)004<1147:TVGPCP > 2.0.CO;2. 
Allan, R. J., and T. J. Ansell, 2006: A new globally complete monthly historical mean sea level pressure data set (HadSLP2): 1850 2004. J. Climate, 19, 5816-5842, doi:10.1175/JCLI3937.1.

Allan, R. P., 2006: Variability in clear-sky longwave radiative cooling of the atmosphere. J. Geophys. Res., 111, D22105, doi:10.1029/2006JD007304.

Bader, J., and M. Latif, 2003: The impact of decadal-scale Indian Ocean sea surface temperature anomalies on Sahelian rainfall and the North Atlantic Oscillation. Geophys. Res. Lett., 30, 2169, doi:10.1029/2003GL018426.

Bellouin, N., J. Rae, A. Jones, C. Johnson, J. Haywood, and O. Boucher, 2011: Aerosol forcing in the Climate Model Intercomparison Project (CMIP5) simulations by HadGEM2-ES and the role of ammonium nitrate. J. Geophys. Res., 116, D20206, doi:10.1029/2011JD016074.

Biasutti, M., I. M. Held, A. H. Sobel, and A. Giannini, 2008: SST forcings and Sahel rainfall variability in simulations of the twentieth and twenty-first centuries. J. Climate, 21, 3471-3486, doi:10.1175/2007JCLI1896.1.

Bollasina, M., Y. Ming, V. Ramaswamy, M. D. Schwarzkopf, and V. Naik, 2014: Contribution of local and remote anthropogenic aerosols to the 20th century weakening of the South Asian monsoon. Geophys. Res. Lett., 41, 680-687, doi:10.1002/ 2013GL058183.

Booth, B. B., N. J. Dunstone, P. R. Halloran, T. Andrews, and N. Bellouin, 2012: Aerosols implicated as a prime driver of twentieth-century North Atlantic climate variability. Nature, 484, 228-233, doi:10.1038/nature10946.

Chang, C.-Y., J. C. H. Chiang, M. F. Wehner, A. Friedman, and R. Ruedy, 2011: Sulfate aerosol control of tropical Atlantic climate over the twentieth century. J. Climate, 24, 2540-2555, doi:10.1175/2010JCLI4065.1.

Charney, J. G., 1975: Dynamics of deserts and drought in Sahel. Quart. J. Roy. Meteor. Soc., 101, 193-202, doi:10.1002/qj.49710142802.

Chou, C., J. D. Neelin, U. Lohmann, and J. Feichter, 2005: Local and remote impacts of aerosol climate forcing on tropical precipitation. J. Climate, 18, 4621-4636, doi:10.1175/JCLI3554.1.

Collins, W. J., and Coauthors, 2011: Development and evaluation of an Earth-system model-HadGEM2. Geophys. Model Dev. Discuss., 4, 997-1062, doi:10.5194/gmdd-4-997-2011.

Dai, A., 2013: Increasing drought under global warming in observations and models. Nat. Climate Change, 3, 52-58, doi:10.1038/ nclimate1633.

Dong, B.-W., and R.-Y. Lu, 2013: Interdecadal enhancement of the Walker circulation over the tropical Pacific in the late 1990s. Adv. Atmos. Sci., 30, 247-262, doi:10.1007/s00376-012-2069-9.

- J. M. Gregory, and R. T. Sutton, 2009: Understanding landsea warming contrast in response to increasing greenhouse gases. Part I: Transient adjustment. J. Climate, 22, 3079-3097, doi:10.1175/2009JCLI2652.1.

Folland, C. K., T. N. Palmer, and D. E. Parker, 1986: Sahel rainfall and worldwide sea temperatures 1901-1985. Nature, 320, 602 607, doi:10.1038/320602a0.

Gettelman, A., and Q. Fu, 2008: Observed and simulated uppertropospheric water vapor feedback. J. Climate, 21, 3282-3289, doi:10.1175/2007JCLI2142.1.

Giannini, A., R. Saravanan, and P. Chang, 2003: Oceanic forcing of Sahel rainfall on interannual to interdecadal time scales. $S c i$ ence, 302, 1027-1030, doi:10.1126/science.1089357.

, and Coauthors, 2013: A unifying view of climate change in the Sahel linking intra-seasonal, interannual and longer time scales. Environ. Res. Lett., 8, 024010, doi:10.1088/ $1748-9326 / 8 / 2 / 024010$
Hansen, J., M. Sato, and R. Ruedy, 1997: Radiative forcing and climate response. J. Geophys. Res., 102, 6831-6864, doi:10.1029/ 96JD03436.

Harris, I., P. D. Jones, T. J. Osborn, and D. H. Lister, 2013: Updated high-resolution grids of monthly climatic observationsThe CRU TS3.10 dataset. Int. J. Climatol., 34, 623-642, doi:10.1002/joc.3711.

Haywood, J. M., A. Jones, N. Bellouin, and D. Stephenson, 2013: Asymmetric forcing from stratospheric aerosols impacts Sahelian rainfall. Nat. Climate Change, 3, 660-665, doi:10.1038/nclimate1857.

Held, I. M., T. L. Delworth, J. Lu, K. L. Findell, and T. R. Knutson, 2005: Simulation of Sahel drought in the 20th and 21st centuries. Proc. Natl. Acad. Sci. USA, 102, 17 891-17 896, doi:10.1073/ pnas.0509057102.

Huang, J., C. Zhang, and J. M. Prospero, 2009: African aerosol and large-scale precipitation variability over West Africa. Environ. Res. Lett., 4, 015006, doi:10.1088/1748-9326/4/1/015006.

Hwang, Y.-T., D. M. W. Frierson, and S. M. Kang, 2013: Anthropogenic sulfate aerosol and the southward shift of tropical precipitation in the late 20th century. Geophys. Res. Lett., 40, 2845-2850, doi:10.1002/grl.50502.

Jones, C., and Coauthors, 2011: The HadGEM2-ES implementation of CMIP5 centennial simulations. Geophys. Model Dev., 4, 543570, doi:10.5194/gmd-4-543-2011.

Kalnay, E., and Coauthors, 1996: The NCEP-NCAR 40-Year Reanalysis Project. Bull. Amer. Meteor. Soc., 77, 437-471, doi:10.1175/1520-0477(1996)077<0437:TNYRP>2.0.CO;2.

Kawase, H., M. Abe, Y. Yamada, T. Takemura, T. Yokohata, and T. Nozawa, 2010: Physical mechanism of long-term drying trend over tropical North Africa. Geophys. Res. Lett., 37, L09706, doi:10.1029/2010GL043038.

Kerr, R. A, 2000: A North Atlantic climate pacemaker for the centuries. Science, 288, 1984-1985, doi:10.1126/ science.288.5473.1984.

Knight, J. R., C. K. Folland, and A. A. Scaife, 2006: Climate impacts of the Atlantic multidecadal oscillation. Geophys. Res. Lett., 33, L17706, doi:10.1029/2006GL026242.

Kucharski, F., A. Bracco, J. H. Yoo, A. M. Tompkins, L. Feudale, P. Ruti, and A. Dell'Aquila, 2009: A Gill-Matsuno-type mechanism explains the tropical Atlantic influence on African and Indian monsoon rainfall. Quart. J. Roy. Meteor. Soc., 135, 569-579, doi:10.1002/qj.406.

- N. Zeng, and E. Kalnay, 2013: A further assessment of vegetation feedback on decadal Sahel rainfall variability. Climate Dyn., 40, 1453-1466, doi:10.1007/s00382-012-1397-x.

Lamarque, J.-F., and Coauthors, 2010: Historical (1850-2000) gridded anthropogenic and biomass burning emissions of reactive gases and aerosols: Methodology and application. Atmos. Chem. Phys., 10, 7017-7039, doi:10.5194/acp-10-7017-2010.

Lau, K. M., K. M. Kim, Y. C. Sud, and G. K. Walker 2009: A GCM study of the response of the atmospheric water cycle of West Africa and the Atlantic to Saharan dust radiative forcing. Ann. Geophys., 27, 4023-4037, doi:10.5194/angeo-27-4023-2009.

Liu, Y., J. C. H. Chiang, C. Chou, and C. M. Patricola, 2014: Atmospheric teleconnection mechanisms of extratropical North Atlantic SST influence on Sahel rainfall. Climate Dyn., doi:10.1007/s00382-014-2094-8, in press.

Lu, J., 2009: The dynamics of the Indian Ocean sea surface temperature forcing of Sahel drought. Climate Dyn., 33, 445-460, doi:10.1007/s00382-009-0596-6.

Martin, E. R., and C. D. Thorncroft, 2014: The impact of the AMO on the West African monsoon annual cycle. Quart. J. Roy. Meteor. Soc., 140, 31-46, doi:10.1002/qj.2107. 
, and B. B. B. Booth, 2014: The multidecadal Atlantic SST-Sahel rainfall teleconnection in CMIP5 simulations. J. Climate, 27, 784-806, doi:10.1175/JCLI-D-13-00242.1.

Minschwaner, K., A. E. Dessler, and P. Sawaengphokhai, 2006: Multimodel analysis of the water vapor feedback in the tropical upper troposphere. J. Climate, 19, 5455-5464, doi:10.1175/JCLI3882.1.

Mitchell, J., C. A. Wilson, and W. M. Cunnington, 1987: On $\mathrm{CO}_{2}$ climate sensitivity and model dependence of results. Quart. J. Roy. Meteor. Soc., 113, 293-322, doi:10.1002/qj.49711347517.

Mohino, E., S. Janicot, and J. Bader, 2011: Sahel rainfall and decadal to multi-decadal sea surface temperature variability. Climate Dyn., 37, 419-440, doi:10.1007/s00382-010-0867-2.

Nicholson, S. E., 2013: The West African Sahel: A review of recent studies on the rainfall regime and its interannual variability ISRN Meteor., 2013, 453521, doi:10.1155/2013/453521.

Randall, D. A., and Coauthors, 2007: Climate models and their evaluation. Climate Change 2007: The Physical Science Basis, S. Solomon et al., Eds., Cambridge University Press, 589-662.

Rayner, N. A., D. E. Parker, E. B. Horton, C. K. Folland, L. V. Alexander, D. P. Rowell, E. C. Kent, and A. Kaplan, 2003: Global analyses of sea surface temperature, sea ice, and night marine air temperature since the late nineteenth century. J. Geophys. Res., 108, 4407, doi:10.1029/2002JD002670.

Rosenfeld, D., U. Lohmann, G. B. Raga, C. D. O’Dowd, M. Kulmala, S. Fuzzi, A. Reissell, and M. O. Andreae, 2008: Flood or drought: How do aerosols affect precipitation? Science, 321, 1309-1313, doi:10.1126/science.1160606.

Rotstayn, L. D., and U. Lohmann, 2002: Tropical rainfall trends and the indirect aerosol effect. J. Climate, 15, 2103-2116, doi:10.1175/1520-0442(2002)015<2103:TRTATI >2.0.CO;2.
Stevens, B., and G. Feingold, 2009: Untangling aerosol effects on clouds and precipitation in a buffered system. Nature, 461, 607-613, doi:10.1038/nature08281.

Tao, W.-K., J.-P. Chen, Z. Li, C. Wang, and C. Zhang, 2012: Impact of aerosols on convective clouds and precipitation. Rev. Geophys., 50, RG2001, doi:10.1029/2011RG000369.

Twomey, S., 1977: Influence of pollution on shortwave albedo of clouds. J. Atmos. Sci., 34, 1149-1152, doi:10.1175/ 1520-0469(1977)034<1149:TIOPOT>2.0.CO;2.

Wang, C., 2006: An overlooked feature of tropical climate: InterPacific-Atlantic variability. Geophys. Res. Lett., 33, L12702, doi:10.1029/2006GL026324.

—, S. Dong, A. T. Evan, G. R. Foltz, and S.-K. Lee, 2012: Multidecadal covariability of North Atlantic sea surface temperature, African dust, Sahel rainfall, and Atlantic hurricanes. J. Climate, 25, 5404-5415, doi:10.1175/JCLI-D-11-00413.1.

Yoshioka, M., N. M. Mahowald, A. J. Conley, W. D. Collins, D. W. Fillmore, C. S. Zender, and D. B. Coleman, 2007: Impact of desert dust radiative forcing on Sahel precipitation: Relative importance of dust compared to sea surface temperature variations, vegetation changes, and greenhouse gas warming. J. Climate, 20, 1445-1467, doi:10.1175/JCLI4056.1.

Zeng, N., J. D. Neelin, K.-M. Lau, and C. J. Tucker, 1999: Enhancement of interdecadal climate variability in the Sahel by vegetation interaction. Science, 286, 1537-1540, doi:10.1126/ science.286.5444.1537.

Zhang, R., and T. L. Delworth, 2006: Impact of Atlantic multidecadal oscillations on India/Sahel rainfall and Atlantic hurricanes. Geophys. Res. Lett., 33, L17712, doi:10.1029/ 2006 GL026267. 